\title{
THE ROLE OF ATMOSPHERIC DEPOSITION IN THE BIOGEOCHEMISTRY OF THE MEDITERRANEAN SEA
}

\author{
Stefano Guerzoni $(*)$ \\ Istituto di Geologia Marina, CNR /via Gobetti, 101 /40129 Bologna, Italy \\ Roy Chester, \\ Oceanography Laboratory,University of Liverpool, P.O. Box 147 /Liverpool L69 3 BX, United Kingdom \\ François Dulac, \\ CEA, MIXTE Lab., Ctr. Faibles Radioactivites/Saclay 709 - CNRS, 91198 Gif-sur-Yvette, France \\ Barak Herut \\ Israel Oceanographic \& Limnological Research/ Tel Shikmona /P.O.Box 8030/31080 Haifa, Israel \\ Marie-Dominique Loÿe-Pilot \\ Ecole Normale Superieure, IBM - CNRS 386/ 1, Rue Maurice Arnoux 792120 - Montrouge, France \\ Chris Measures \\ Dept.of Oceanography, University of Hawaii at Mãnoa / 1000 Pope Road /Honolulu, HI 96822 - USA \\ Christophe Migon \\ C.N.R.S./ Laboratoire de Physique et Chimie Marines/ B.P. 8 /06230 - Villefranche-sur-mer, France \\ Emanuela Molinaroli \\ Dip. Scienze Ambientali, Università di Venezia/ Dorsoduro 2137 /30123 Venezia, Italia \\ Cyril Moulin \\ CEA, MIXTE Lab., Ctr. Faibles Radioactivites /Saclay 709 - CNRS, 91198 Gif-sur-Yvette, France \\ Paolo Rossini \\ Istituto di Geologia Marina, CNR /via Gobetti, 101 /40129 Bologna, Italy \\ Cemal Saydam \\ Institute of Marine Science -METU/ P.O. Box 28 /33731 Erdemli-Içel, Turkey \\ Alexandre Soudine \\ WMO, Environment Division/ Case postale n² $2300 / \mathrm{CH}-1211$ Geneva 2, Switzerland \\ Patrizia Ziveri \\ Geomarine Center, Vrije Universiteit Amsterdam/ 1081 HV Amsterdam, The Netherlands \\ $\left({ }^{*}\right)$ This paper is an expansion of discussions held at the CIESM-CNR Workshop in Bologna , 8-11 \\ October 1997.
}

\footnotetext{
Abstract

Estimates of atmospheric inputs to the Mediterranean (MED) and some coastal areas are reviewed, and uncertainities in these estimates considered. Both the magnitude and the mineralogical composition of atmospheric dust inputs indicate that eolian deposition is an important $(50 \%)$ or prevailing (>80\%) contribution to sediments in the offshore waters of the entire
} 
Mediterranean (MED) basin. Model data for trace metals and nutrients indicate that the atmosphere delivers more than half the lead and nitrogen, one-third of total phosphorus, and $10 \%$ of the zinc entering the entire basin. Measured data in sub-basins, such as the north-western MED and northern Adriatic indicate an even greater proportion of atmospheric versus riverine inputs. When dissolved fluxes are compared (the form most likely to impinge on surface water biogeochemical cycles), the atmosphere is found to be 5 to 50 times more important than rivers for dissolved $\mathrm{Zn}$ and 15 to 30 times more important for $\mathrm{Pb}$ fluxes. Neglecting co-limitation by other nutrients, new production supported by atmospheric nitrogen deposition ranges from $2-4 \mathrm{~g} \mathrm{C} \mathrm{m}$ ${ }^{2} \mathrm{yr}^{-1}$, whereas atmospheric phosphorus deposition appears to support less than $1 \mathrm{~g} \mathrm{C} \mathrm{m}^{-2} \mathrm{yr}^{-1}$. In spite of the apparently small contribution of atmospheric deposition to overall production in the basin it has been suggested that certain episodes of phytoplankton blooms are triggered by atmospheric deposition of N, P or Fe. Future studies are needed to clarify the extent and causal links between these episodic blooms and atmospheric/oceanographic forcing functions. A scientific program aimed at elucidating the possible biogeochemical effects of Saharan outbreaks in the MED through direct sampling of the ocean and atmosphere before and after such events is therefore highly recommended.

\section{Introduction}

Over the past two decades it has become apparent that the atmosphere is not only a significant but in some cases the dominant pathway by which both natural and pollutant materials are transported from continents to both coastal and open seas. These substances include mineral dust, plant residues, heavy metals, nitrogen species from combustion processes and fertilisers, pesticides, and a wide range of synthetic organic compounds from industrial and domestic sources. Some of these substances, such as lead and some chlorinated hydrocarbons, when carried into oceans by the atmosphere, are potentially harmful to marine biological systems. Others, such as nitrogen species, phosphorus and iron, are nutrients and may enhance marine productivity. For some substances (e.g. aluminium, cadmium, lead, and some rare earth elements), atmospheric flux has an important impact on their oceanic chemical cycles. Atmospheric inputs may thus exert many different effects on the marine environment, and it is necessary to understand the magnitude and geographical distribution of the atmospheric fluxes of these materials to both coastal and open seas. Indeed, there have recently been a number of intensive studies of atmospheric inputs to coastal waters in North America and Europe, with several studies also devoted to investigating these processes in open oceans.

The most complete review of this subject, updated to the early 1990s, was a report by the Group of Experts on the Scientific Aspects of Marine Environmental Protection (GESAMP, 1989), much of which was subsequently published as a review article in the scientific literature (DUCE et al., 1991). The present paper briefly reviews results from several of these studies, especially those related to the Mediterranean Sea.

The biogeochemical effects of mineral dust deposition to the water surface are of interest from several perspectives. The observation of more than 30 -fold increases in dust deposition during glacial periods suggests a link between climatic oscillations and carbon cycling in the surface ocean on global and glacial scales (MARTIN, 1990). This link is created through the roles played by eolian deposition in supplying $\mathrm{Fe}$ to remote parts of the open ocean and by iron limitation in controlling primary production. In these high-nutrient/low-chlorophyll (HNLC) regions, there may be a direct connection between atmospheric and biological processes (MARTIN, 1990; KUMAR et al., 1995). 
Dust input to the nutrient-limited Mediterranean (MED) basin $\left(2.3 \times 10^{6} \mathrm{~km}^{2}\right)$ is one of the greatest in the contemporary ocean $\left(20-50 \times 10^{6}\right.$ tons $\left.\mathrm{yr}^{-1}\right)$ and it is thus a natural laboratory in which to study the effects of dust deposition on the surface ocean in a setting that is distinct from the HNLC regions (COALE et al., 1996). There have been several hypotheses suggesting that this large dust input is responsible for biogeochemical effects, although no concerted scientific program aimed at elucidating these effects directly has yet been set up.

The aim of the present paper is to review current understanding of the magnitude and effects of dust inputs to the MED and to highlight important areas of uncertainty. Section 1 considers the magnitude of atmospheric dust inputs and problems related to their estimates. Section 2 compares fluxes of trace elements from atmospheric and riverine sources and considers evidence that atmospheric inputs affect the chemistry of surface waters in the MED. Section 3 looks at the role played by atmospheric processes in delivering nutrients to the surface MED and their spatial effects. Section 4 considers current hypotheses of mechanisms by which atmospheric deposition is believed to affect surface water biogeochemical cycles, focusing particularly on the roles of phosphate and iron, and reviews what evidence exists to evaluate them.

\section{Magnitude and mineralogical composition of atmospheric mineral dust input}

Budgets and residence time estimates for trace metals and nutrients in the oceans have traditionally been based on riverine fluxes and have neglected atmospheric and other inputs. For most major and minor components of seawater, the atmosphere has generally been assumed to be a secondary source. However, over the last 20 years systematic studies of atmospheric inputs to the MED have been undertaken, and sufficient data are now available to allow fairly reliable estimates to be made. The most comprehensive study is that prepared by GESAMP (1989), together with several recent reviews devoted to the Western MED within the EROS 2000 project (MILLIMAN and MARTIN, 1997).

For rivers, there is the major problem of understanding and quantifying transport through estuarine and coastal regions to deep waters. MILLIMAN et al. (1995) and GESAMP (1989) both attempted to address this problem by compiling run-off data for countries surrounding the MED. It is important to note, however, that many of these data reflect historic not present-day discharges. A good example of this is the decreased flow to the western MED, as illustrated in the introduction to the EROS-2000 DSR-II special issue (MILLIMAN and MARTIN, 1997). The Rhone and many Italian rivers currently have discharges very similar to those of 40 years ago, whereas most Spanish and north African rivers have been dammed in the past 20-30 years.

Atmospheric flux estimates suffer from an undersampling problem. The atmosphere is a very dynamic compartment of the earth's system, within which concentrations of reactive gases and particulate matter vary considerably in space and time. This variability ranges from rapid day-to-day changes in pollutant concentrations (lead, cadmium, NOx, SOx) to massive temporal and spatial changes in dust 
loading over the entire MED (Tab. 1.1), as a result of dust storms in North Africa (GUERZONI et al., 1997; BERGAMETTI, 1989; DULAC et al., 1989, 1996; LOŸE-PILOT and MARTIN, 1996).

Tab. 1.1 - Range of insoluble particulate load concentrations in air and rain during two years at Sardinia (39N, 9'E: from Guerzoni et al., 1997).

\begin{tabular}{lcc}
\hline & air $\left(\mu \mathrm{g} \mathrm{m}^{-3}\right)$ & rain $\left(\mathrm{mg} \mathrm{l}^{-1}\right)$ \\
\hline Background & $1-3$ & $0.1-10$ \\
Desert-enriched & 20 & $10-50$ \\
Saharan outbreaks & 44 & $50-500$ \\
Maximum recorded & 110 & 510 \\
\hline
\end{tabular}

background : $\mathrm{Al} / \mathrm{Si}<0.3 ; \mathrm{Ca}<2 \%$; associated rain $\mathrm{pH}<5.60 ; \mathrm{Ca}<200 \mathrm{meq}^{-1}$

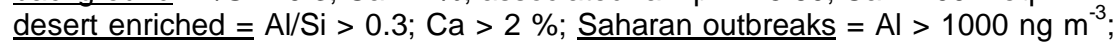
$\mathrm{Al} / \mathrm{Si}>0.4 ; \mathrm{Ca}>4 \%$.

The high spatial and temporal variability of dust transport and deposition, coupled with the short duration of oceanographic research cruises, has made it difficult to obtain good estimates of dust deposition to those areas of the open ocean devoid of islands at which continuous sampling can be undertaken.

Encouragingly, however, recent results from ship-board collections of aerosol metals over the North Sea, where a steep spatial gradient in aerosol concentration is found (YAAQUB et al., 1991), are comparable to samples collected at the coast (CHESTER et al., 1993; KANE et al., 1994). This finding suggests that atmospheric fluxes estimated from coastal sites may be extrapolated to adjacent marine areas. A similar result was found in the Western MED (WMED) where MARTIN et al. (1989) and CHESTER et al. (1993) showed that background aerosols at sea have similar $\mathrm{Pb}$ and $\mathrm{Cd}$ values to those collected at a remote coastal station in Sardinia (GUERZONI et al., 1997).

Despite the shortcomings of these estimates, for many trace elements (e.g., $\mathrm{Al}, \mathrm{Pb}, \mathrm{Zn}$ ), it has been shown that the local dissolved flux from partial dissolution of eolian dust in surface waters is much greater than that carried by the Rhone and Po rivers into the WMED and Adriatic respectively (GUIEU et al., 1997; GUERZONI et al., in press). Even where river fluxes appear to be similar in magnitude to those of dust, estuarine and near-shore removal processes attenuate river fluxes severely, often resulting in little of the riverine signal penetrating into offshore regions. An exception to this is $\mathrm{Cd}$, which forms stable and soluble complexes with chlorides and may also be desorbed from river-borne particulate during estuarine mixing, so that in this case the input very often influences open basin waters (BOYLE et al., 1985; Elbaz-Poulichet et al., 1989).

\subsection{Atmospheric mineral particle fluxes and mineralogy}


Beside the undersampling problem, several theoretical problems also hinder our ability to derive atmospheric flux estimates to the ocean from atmospheric suspended loads. It is therefore useful to compare the measured data with the results of GESAMP flux calculations (DUCE, 1991).

Fig. 1.1 and Tab. 1.2 list most of the coastal stations where long (2-11 yrs) time series data are available together with an inventory of mean annual bulk dust fluxes around the Mediterranean. Flux values are deduced from a combination of aerosol suspended loads, dry, wet and bulk deposition samples. Sampling frequency at the various sites ranged from a few days (aerosols) to a few weeks (bulk).

Mean annual deposition mass fluxes of mineral dust for the WMED range from 3-12 $\mathrm{g} \mathrm{m}^{-2} \mathrm{yr}^{-1}$, whereas much higher values are found (20-50 $\left.\mathrm{g} \mathrm{m}^{-2} \mathrm{yr}^{-1}\right)$ in the Eastern MED (EMED). The measured data are higher than those calculated with the GESAMP model using precipitation rates and a scavenging ratio (SR) of 200. As the SR for the MED is probably higher (GUERZONI et al., 1996), mass fluxes were recalculated using an SR of 500, and are listed in Tab. 1.2. When SR=500 is used, the two estimates agree very well.

With the data from table 1.2 we can calculate mean values of 8,12 and $35 \mathrm{~g} \mathrm{~m}^{-2} \mathrm{yr}^{-1}$ for WMED, CMED and EMED respectively, and use these values to estimate the total annual atmospheric dust flux, which turned out to be $\sim 40 \times 10^{6}$ tons for the whole Mediterranean basin (Tab. 1.3). This estimate may be compared to total riverine discharge estimates recently revised by LOICZ (MILLIMAN et al., 1995). The sub-areas indicated by GESAMP (Nos. 1 to 10, shown in Fig. 1.1) were used for calculations.

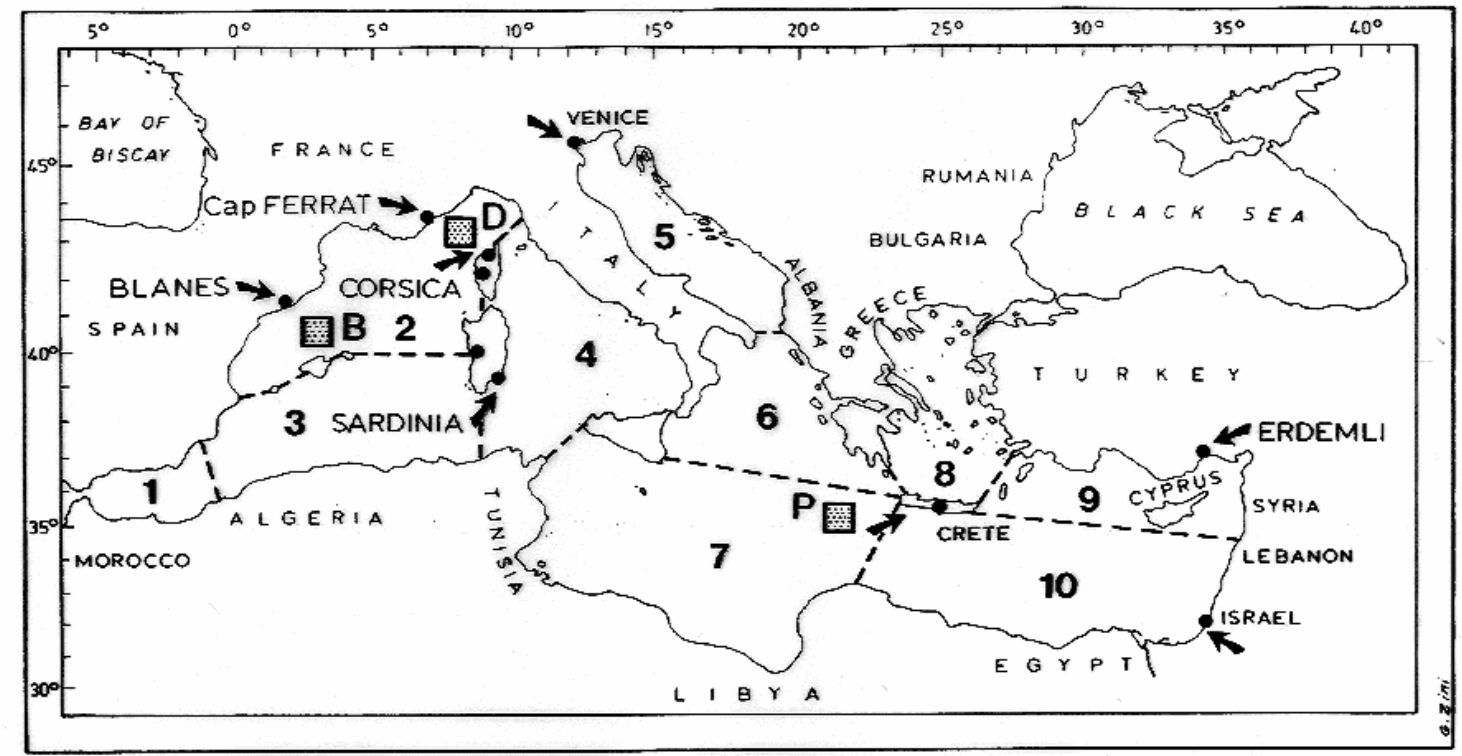

Fig. 1.1 - Arrows indicate the location of sampling sites for which time series of atmospheric data are available. Squares: sediment trap locations ( $B=$ Balear; $D=$ Dyfamed; $P=P a l e o f l u x)$. Division in sub-areas 1-10 according to UNEP (1984) for budget calculations. 
Tab. 1.2 - Mean annual (and range) atmospheric mass fluxes $\left(\mathrm{g} \mathrm{m}^{-2}\right)$ measured at various coastal sites (refer to Fig.1.1 for site locations). Mean fluxes for three subbasins calculated by averaging Spain, SE France, Sardinia and Corsica for WMED, Corsica, NE Italy and Crete for CMED, and Crete and Israel for EMED. Estimates from GESAMP model (DUCE, 1991) calculated with scavenging ratio values of 200 and 500 respectively.

\begin{tabular}{|c|c|c|c|c|}
\hline site & $\begin{array}{l}\text { flux } \\
\mathrm{g} \mathrm{m}^{-2}\end{array}$ & sub-basin & $\begin{array}{l}\text { mean } \\
\mathrm{g} \mathrm{m}^{-2}\end{array}$ & $\begin{array}{l}\text { GESAMP } \\
S R=200(500)\end{array}$ \\
\hline $\begin{array}{l}\text { Spain }^{\mathrm{a}} \\
\text { SE France }^{\mathrm{b}}\end{array}$ & $\begin{array}{l}5(1-11) \\
4(2-11)\end{array}$ & & & \\
\hline Sardinia $^{c}$ & $8(2-12)$ & WMED & 8 & $3.4(8)$ \\
\hline Corsica $^{\mathrm{d}}$ & $12(4-25)$ & & & \\
\hline NE Italy & $3(2-6)$ & CMED & 12 & $7(18)$ \\
\hline Crete $^{f}$ & $21(6-46)$ & & & \\
\hline |srael| $^{g}$ & $50(36-72)$ & EMED & 35 & $14(35)$ \\
\hline
\end{tabular}

(a) CARRATALA et al. (1996); RODA et al. (1993); (b) GUEIU et al. (1997); (c) GUERZONI et al. (1997); LE BOLLOCH and GUERZONI (1995); (d) LOŸE-PILOT et al. (1996); BERGAMETTI et al. (1989); (e) GUERZONI et al. (in press); ROSSINI and GUERZONI (1996); (f) NIHLEN and MATTSSON (1989); PYE (1992); (g) HERUT and KROM (1996).

Table 1.3 - Comparison of riverine discharge $(R)$ and atmospheric $(A)$ input of insoluble particles to Mediterranean Sea. Data on riverine discharge are from MILLIMAN et al. (1995). Atmospheric mass inputs derived from average fluxes in three sub-basins (west to east) of 8-12-35 $\mathrm{g} \mathrm{m}^{-2} \mathrm{yr}^{-1}$, respectively (see Tab. 1.2 and text for explanation).

\begin{tabular}{|c|c|c|c|c|}
\hline \multirow[b]{2}{*}{ Sub-basin } & \multirow{2}{*}{$\begin{array}{c}\text { Area } \\
\left(10^{6} \mathrm{~km}^{2}\right)\end{array}$} & \multicolumn{3}{|c|}{ mass $\left(10^{6}\right.$ tons $)$} \\
\hline & & $\mathbf{R}$ & A & $\% A$ \\
\hline WMED & 0.84 & 30 & 7 & 19 \\
\hline CMED & 0.80 & 35 & 10 & 22 \\
\hline EMED & 0.70 & 10 & 24 & 70 \\
\hline Total & 2.34 & $75^{\star}$ & 41 & 35 \\
\hline
\end{tabular}

$\left({ }^{*}\right)$ if $2 / 3$ of riverine input remains on the continental shelf $(<100 \mathrm{~m})$ then the offshore riverine discharge is reduced to $25 \times 10^{6}$ tons, and the atmospheric contribution increases to $\sim 60 \%$.

\subsubsection{Mineralogy}

LOŸE-PILOT et al. (1986) and GUERZONI et al. (1997) have shown the relationship between eolian deposition and deep sea sedimentation, and found that the atmosphere contributes on average from 10 to $30 \%$ of recent sediments. Here, we highlight differences among sub-basins and the possible role of mineralogy in identifying the sites where the atmospheric input is most important.

The mineralogical signature may be used as an indicator of dust origin. Mineral dust mainly consists of a mixture of silicates (clay minerals, feldspar, quartz) associated with carbonates. The abundance of each of these minerals in dust is highly variable, mainly reflecting the source composition and its 
evolution during transport. Several studies have examined specific minerals within the clay to identify source regions. For example, palygorskite has been used as an indicator of dusts of north-west African origin in samples collected over the MED (TOMADIN and LENAZ, 1989; MOLINAROLI and IBBA, 1995; MOLINAROLI, 1996).

Another approach is to look for mineral associations which are characteristic of dust sources. For example, illite is an ubiquitous clay and is not characteristic of any particular weathering regime, whereas kaolinite, which may also be produced in a variety of weathering conditions, is characteristic of desert weathering regimes. A comparison of the mineralogy of dusts collected throughout the MED shows that illite reaches its highest value in the CMED and its lowest in the EMED (Tab.1.4). In the CMED mixed dusts are observed. Kaolinite is more abundant in dust originating from the eastern compared to western Sahara, the highest concentrations being observed off the Egyptian coast. Smectite is very common in the EMED but not in the WMED. A comparison between dust and sediment has been attempted (CAQUINEAU et al., in press) by considering the difference between illite and kaolinite distributions in the Mediterranean and the illite/kaolinite ratio in the African source dust. The comparison between the $\mathrm{I} / \mathrm{K}$ ratio in dust and sediments is shown in Tab 1.4. WMED dust transported from the Sahara originating from north-west Africa shows an $\mathrm{I} / \mathrm{K}$ ratio of 1.8. CAQUINEAU et al. (in press) observed a range of $\mathrm{I} / \mathrm{K}$ values from 2.4 to 1.6 in north-west Africa. The similarity of the $\mathrm{I} / \mathrm{K}$ ratio between dust and sediment $(\mathrm{I} / \mathrm{K}=1.8)$ in the WMED indicates that the major contribution to sedimentation in this region is from dust deposition from the western Sahara. This conclusion contradicts data from Table 1.3, which indicates an overwhelming river contribution in this region. The fact that the sediment $\mathrm{I} / \mathrm{K}$ ratio appears to be set by atmospheric dust probably indicates that a large fraction of the riverborne material is deposited on shelves.

Tab. 1.4 - Average of clay mineral compositions and $\mathrm{I} / \mathrm{K}$ ratio in Saharan dusts (D) and sediments (S) in MED basin.

\begin{tabular}{llllll}
\hline Sample & Illite & Chlorite & Kaolinite & Smectite & I/K \\
\hline WMED (D) & 53 & 9 & 29 & 9 & 1.8 \\
WMED (S) & 48 & 10 & 26 & 16 & 1.8 \\
CMED (D) & 66 & 12 & 16 & 3 & 4.0 \\
CMED (S) & 45 & 12 & 13 & 30 & 3.5 \\
EMED (D) & 32 & 5 & 38 & 25 & 0.8 \\
EMED (S) & 15 & 5 & 35 & 45 & 0.4 \\
\hline
\end{tabular}

This average was compiled using data from several authors:

CHESTER et al. (1984) (3 samples); MAZZUCCOTELLI et al. (1986) (3 samples); MOLINAROLI (1996) (10 samples) for the WMED.

LENAZ et al. (1988) (5 samples) for the CMED.

CHESTER et al. (1977) (7 samples) GANOR and FONER (1996); (17 samples);

TOMADIN and LENAZ (1989) (3 samples) for the south-EMED

TOMADIN (1981) (3 samples) for the (S) WMED

TOMADIN and BORGHINI (1987) (4 samples) for the (S) CMED

VENKATARATHNAM and RYAN (1971) (20 samples) for the(S) EMED 
The CMED has an average $\mathrm{I} / \mathrm{K}$ ratio of 4.0 in dust and 3.5 in sediments. This very high ratio shows that the dust is a mixture of Saharan and background dusts (European), since CAQUINEAU et al. (in press) demonstrated that the $\mathrm{l} / \mathrm{K}$ ratio is always $<2.4$ in African regions.

The EMED has a low $\mathrm{I} / \mathrm{K}$ ratio $(0.8)$ in dust and 0.4 in sediments. A relatively low $\mathrm{I} / \mathrm{K}$ ratio $(0.7)$ is associated with north east African sources by CAQUINEAU et al. (in press). The similarity between dust and sediment values again indicates that the major contribution to sedimentation is from dust deposition, in particular from the eastern Sahara.

\subsection{Sediment trap estimates}

Many sediment trap studies have been or are being carried out in the MED, e.g. Mediterranean Targeted Projects 1 and 2 (MTP1 and MTP2), but very few of these are useful for studying dust deposition, mainly because of their location relative to river inputs.

For instance, among the traps in the WMED, very different results have been derived from those deployed in the Balearic basin (39N, 3E; "B" in $F$ ig. 1.1) with mass fluxes of $50-70 \mathrm{~g} \mathrm{~m}^{-2} \mathrm{yr}^{-1}$, compared to the DYFAMED site (439N, 8E; "D" in Fig . 1.1) where average fluxes are 31-35 $\mathrm{g} \mathrm{m}^{-2} \mathrm{yr}^{-1}$. In addition, the relative contribution of the lithogenic fraction is different between the two sites $(60 \%$ and $25 \%$, respectively). The high flux and lithogenic contribution to the Balearic site is probably related to bottom resuspension and coastal run-off.

The trap used in Paleoflux, MARFLUX (34N, 20E; ZI VERI et al., 1996; "P" in Fig. 1.1) is in the best location for dust flux measurement in the EMED, since river discharge is negligible in this region. The total annual average flux recorded in this 3000m deep trap deployed between November 1991 and August 1994, was around $25 \mathrm{~g} \mathrm{~m}^{-2} \mathrm{yr}^{-1}$, with approximately $60 \%$ of lithogenic origin (RUTTEN et al., in press; ZIVERI et al., submitted).

HEUSSNER and MONACO (1996) showed that two flux gradients of total mass are evident in the MED, and that they are related to trophic conditions. A gradient of decreasing flux is seen on the scale of the entire MED basin from west to east, roughly corresponding to the degree of oligotrophy. Within each sub-basin, a second gradient of trophic conditions appears, of decreasing flux from north to south. The inorganic carbon flux is observed to be slightly higher in the EMED, perhaps related to desert-derived carbonate inputs. The above authors conclude that seasonal variations in fluxes in the traps are essentially due to changes in continental input rates to the MED system, i.e., direct deposition of dust through rain and the effect of rain-induced river run-off (HEUSSNER and MONACO, 1996). The sensitivity of traps to river run-off explains why few of these sites can be used for absolute and relative quantification of Saharan dust export flux to the MED. In fact, as far as we are aware, it has been difficult (if not impossible) to distinguish between lithogenic material from dust and that from river discharge in trap samples.

Despite these problems, trap data from the DYFAMED (WMED) and Paleoflux (EMED) sites appear to be promising. At both sites, the lithogenic flux appears to be similar to or smaller than the eolian fluxes 
estimated for the region from coastal sites (Tab. 1.2). It is very important that, in future trap work, wherever possible, sites that are suitable for the task of quantifying dust deposition are chosen. The EMED is a particularly important region that needs more coverage of eolian deposition from sediment traps.

\subsection{Remote sensing and modelling}

In a series of recent papers, DULAC et al. (1996) and MOULIN et al. (1997a), presented an analysis of historical Meteosat data, which monitored dust export from Africa over the Mediterranean on a quasidaily basis between June 1983 and December 1994. These authors showed that, despite large daily variability, there were clear seasonal cycles with minima during the dry season (November, December and January). The general pattern is that dust transport begins over the eastern basin in spring and spreads over the western basin in summer.

Tentative estimates of deposition fluxes were made from Meteosat vertically integrated dust concentrations, using simple deposition velocity approaches, on a yearly time scale at the DYFAMED station, and for shorter periods in the western basin (DULAC et al., 1996). A similar paper was published with results for the DYFAMED station in the Ligurian Sea (MOULIN et al., 1997b). The former authors compared Meteosat data with measured aerosols at the Corsica site for a six-month period $(1 / 2 / 87-31 / 8 / 87)$ and found the average measured flux was $0.024 \mathrm{~g} \mathrm{~m}^{-2}$ day $^{-1}$ (equivalent to approximately $\left.9 \mathrm{~g} \mathrm{~m}^{-2} \mathrm{yr}^{-1}\right)$, whereas Meteosat data yielded a flux of $0.01-0.03 \mathrm{~g} \mathrm{~m}^{-2}$ day $^{-1}\left(4-11 \mathrm{~g} \mathrm{~m}^{-2}\right.$ $\mathrm{yr}^{-1}$ ) for the same period.

DULAC et al. (1996) also compared Meteosat-derived atmospheric fluxes in 1987 and 1988 with seawater dust fluxes measured in sediment traps at $200 \mathrm{~m}$ water depth during the same period at the DYFAMED station. If the periods with sediment trap data are examined, there are results for 364 days over a 2-year period. Seasonal variations are shown in Fig. 1.2. The minimum and maximum Meteosat-derived fluxes bracket the trap fluxes in summer and autumn 1987 and again between spring and autumn 1988. In both winters (1987 and 1988) the trap flux is greater than the maximum Meteosat estimates.

The Meteosat estimates show a similar range for both years (3.5-10.8 and 3.6-11.0 $\left.\mathrm{g} \mathrm{m}^{-2} \mathrm{yr}^{-1}\right)$ while the sediment trap data show distinctly different fluxes (12 and $9 \mathrm{~g} \mathrm{~m}^{-2} \mathrm{yr}^{-1}$ ) in the two years. Some of this variability may be due to various short-term hydrological and biological processes that control the downward transport of particulate material in the water column. The susceptibility of trap data to shortterm variations is shown in Fig 1.3, showing contemporaneous trap fluxes and Meteosat estimates.

\section{Magnitude and fate of atmospheric trace metal inputs}

\subsection{Trace metal concentrations in air}

Aerosols transported to the MED may be considered to consist of anthropogenic-rich "background" materials supplied continuously from Europe, upon which sporadic pulses of Saharan crust-rich dust 


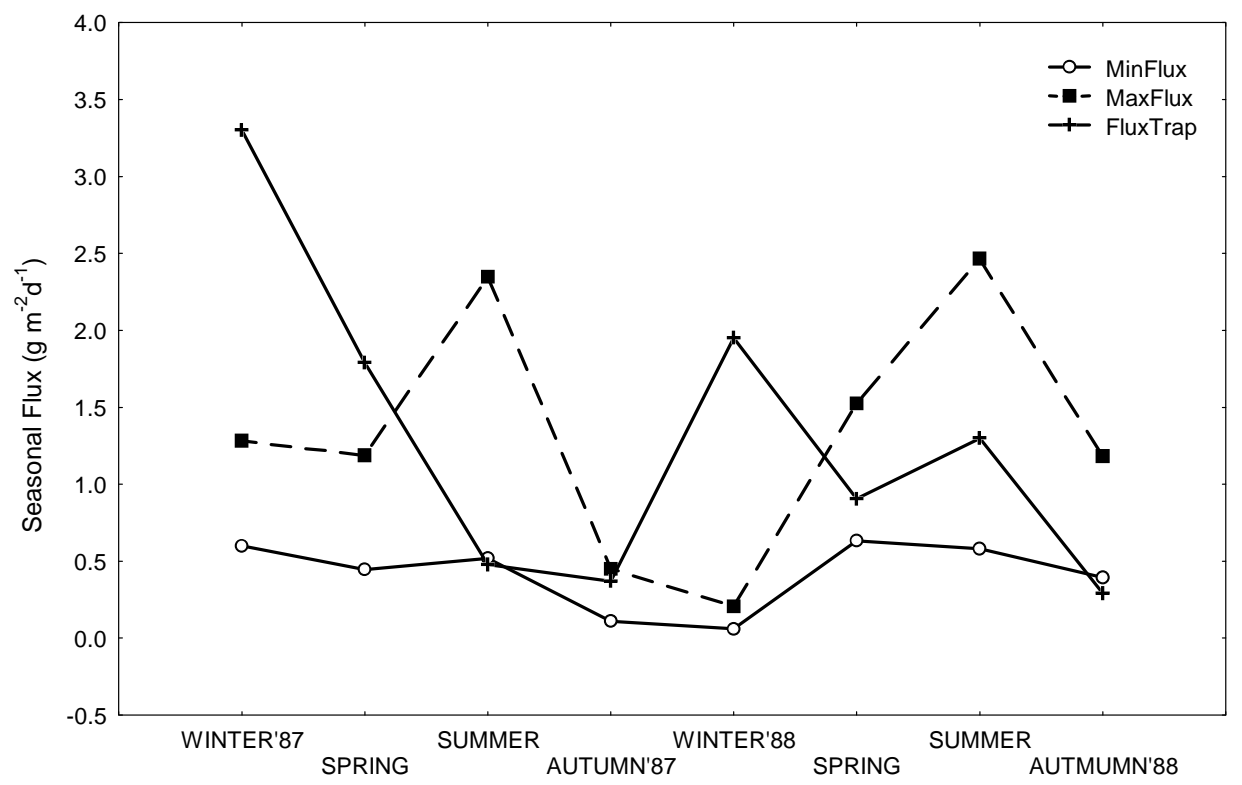

Fig. 1.2 - Seasonal Meteosat-derived $(\mathrm{min} / \mathrm{max})$ and sediment trap terrigenous fluxes at Dyfamed station, 1987-1988.

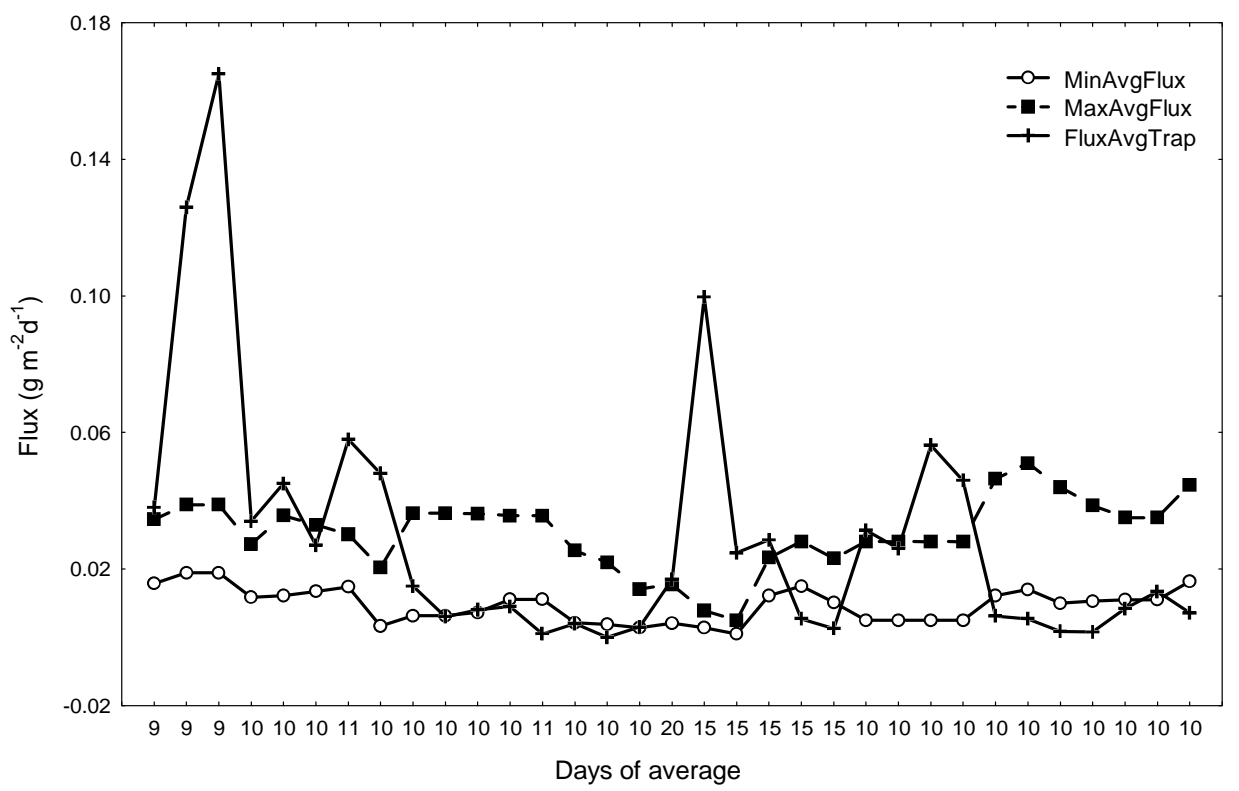

Fig. 1.3 - Time variations (seasonal scale as above) of Meteosat-derived and trap terrigenous fluxes (number of days is integration time of traps).

are superimposed. These two "end-member" aerosols have strikingly different trace metal composition, and this is clear in samples collected on board as well as at coastal stations (see Tab. 2.1). 
Tab. 2.1 - Mean trace metal concentrations (conc. units: $\mathrm{ng} \mathrm{m}^{-3}$ of air) and $\mathrm{EF}_{\text {crust }}$ values for European anthropogenic-dominated and Saharan crust-dominated particulate aerosol populations collected over Tyrrhenian Sea $(n=9$, CHESTER et al.,1984 ) and at Sardinia ( $\mathrm{n}=55$, GUERZONI et al., in press).

\begin{tabular}{ccccc}
\hline & $\begin{array}{c}\text { European anthropogenic-dominated } \\
\text { aerosol population } \\
(\mathrm{n}=5+48)\end{array}$ & \multicolumn{2}{c}{$\begin{array}{c}\text { Saharan crust-dominated } \\
\text { aerosol population } \\
(\mathrm{n}=4+7)\end{array}$} \\
\hline & $\begin{array}{c}\text { Concentration } \\
\text { ship-Sardinia }\end{array}$ & $\begin{array}{c}\text { EF } \\
\text { ship-Sardinia }\end{array}$ & $\begin{array}{c}\text { Concentration } \\
\text { ship-Sardinia }\end{array}$ & $\begin{array}{c}\text { EF crust } \\
\text { ship-Sardinia }\end{array}$ \\
\hline $\mathrm{Al}$ & $112-210$ & $1.0-1.0$ & $2000-2929$ & $1.0-1.0$ \\
$\mathrm{Fe}$ & $117-84$ & $1.7-8.3$ & $1249-1139$ & $0.9-1.7$ \\
$\mathrm{Mn}$ & $4.3-5.4$ & $3.5-1.5$ & $19-24$ & $0.8-1.1$ \\
$\mathrm{Cr}$ & $1.0-0.5$ & $8.6-3.3$ & $4.9-3.3$ & $2.9-1.1$ \\
$\mathrm{Ni}$ & $1.3-5.3$ & $15-21$ & $3.1-7.3$ & $2.8-4.1$ \\
$\mathrm{Zn}$ & $12-22$ & $120-63$ & $8-28$ & $6-18$ \\
$\mathrm{~Pb}$ & 1112 & $767-550$ & $7-25$ & $46-66$ \\
$\mathrm{Cd}$ & $0.44-017$ & $1219-80$ & $0.31-0.08$ & $96-12$ \\
\hline
\end{tabular}

Many studies have documented the airborne concentrations of trace metals over the Mediterranean Sea (DULAC et al., 1987; GUERZONI et al., 1988; BERGAMETTI et al., 1989; CHESTER et al., 1990, 1993; MIGON and CACCIA, 1990; MATEU et al., 1993; MIGON et al., 1993; Sandroni and Migon, 1997). Most metals have a relatively short residence time in the troposphere (between a few days and a few weeks; BERGAMETTI, 1987; BUAT-MÉNARD, 1993). They are not well mixed in the atmosphere and thus aerosols and rainwater are expected to exhibit strong spatial and temporal variability (BUAT-MÉNARD, 1993). However, while seasonal variability is observed in the NW Mediterranean (NICOLAS et al., 1995), spatial variability is rather low for metals such as $\mathrm{Al}, \mathrm{Cd}, \mathrm{Cu}, \mathrm{Fe}, \mathrm{Pb}$ and $\mathrm{Zn}$, and the annual averages from 7 coastal sampling sites are within the same order of magnitude (Tab. 2.2). (CHESTER et al., 1990, 1993; GUIEU et al., 1997; GUERZONI et al., 1996; SANDRONI and MIGON, 1997).

Tab. 2.2 - Average trace metal concentrations and EFcrust values for particulate aerosols from a number of Mediterranean Sea sites (conc. units: $\mathrm{ng} \mathrm{m}^{-3}$ of air)

\begin{tabular}{|c|c|c|c|c|c|c|c|c|c|c|c|c|}
\hline \multirow[b]{3}{*}{$\mathrm{Al}$} & \multicolumn{2}{|c|}{ Spain ${ }^{1}$} & \multicolumn{2}{|c|}{ Corsica ${ }^{2}$} & \multicolumn{2}{|c|}{ Sardinia $^{3}$} & \multicolumn{2}{|c|}{ Erdemli $^{4}$} & \multicolumn{2}{|c|}{ Cap Ferrat $^{5}$} & \multicolumn{2}{|c|}{ Vignola $^{6}$} \\
\hline & Conc. & $\mathrm{EF}_{\text {crust }}$ & Conc. & $\mathrm{EF}_{\text {crust }}$ & Conc. & $\mathrm{EF}_{\text {crust }}$ & & & Conc. & $E F_{\text {crust }}$ & Conc. & $\mathrm{EF}_{\text {crust }}$ \\
\hline & 398 & 1 & 168 & 1 & 480 & 1 & 680 & 1 & 370 & 1 & 109 & 1 \\
\hline $\mathrm{Fe}$ & 316 & 1.3 & 144 & 1.25 & 278 & 0.85 & 685 & 1.5 & 320 & 1.3 & & \\
\hline $\mathrm{Mn}$ & 10 & 2.2 & 4.3 & 2.7 & 7.4 & 1.3 & 12.6 & 1.6 & 11 & 262 & 1.7 & 1.4 \\
\hline $\mathrm{Cr}$ & 1.8 & 3.4 & - & - & 0.51 & 0.89 & 10.8 & 13 & 2.5 & 5.6 & 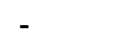 & $\cdot 0$ \\
\hline $\mathrm{Cu}$ & 7.9 & 29 & 2.1 & 18 & 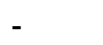 & - & - & 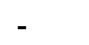 & 6.2 & 24 & 1.9 & 26 \\
\hline $\mathrm{Zn}$ & 50 & 148 & 19 & 133 & 21 & 52 & 19 & 33 & 41 & 13 & 12 & 130 \\
\hline $\mathrm{Pb}$ & 50 & 837 & 16 & 635 & 14 & 194 & 30 & 294 & 58 & 1045 & 9 & 550 \\
\hline $\mathrm{Cd}$ & 0.60 & 628 & 0.66 & 1633 & 0.30 & 260 & 0.19 & 116 & 0.60 & 676 & 0.11 & 423 \\
\hline
\end{tabular}

(1) CHESTER et al. (1993); (2) BERGAMETTI et al. (1989); (3) KEYSE (1995), GUERZONI et al. (1996); (4) KUBILAY and SAYDAM (1995); (5) CHESTER et al. (1990); (6) MIGON et al. (1993)

\subsection{Metal fluxes (total, dry, wet)}

Several authors who have attempted to estimate the atmospheric fluxes of metals to the surface ocean (CHESTER et al., 1989; DULAC et al., 1989; GUIEU et al., 1991; MIGON et al., 1991; 
GUERZONI et al., 1993; NICOLAS et al., 1995; MIGON et al., 1997) have pointed out the difficulties encountered in quantifying the different modes of atmospheric inputs, i.e. wet/dry/total and dissolved/particulate. While evaluation of wet inputs, calculated from rainwater concentration and rainfall amount, is generally reliable, that of dry deposition is more problematic. It has been calculated by a number of methods: i) on the basis of experimental cascade impactor data (e.g., BERGAMETTI, 1987; REMOUDAKI, 1990); ii) from theoretical models (e.g., DULAC et al., 1989); and iii) with surrogate surfaces (e.g., DOLSKE and GATZ, 1985; BAEYENS et al., 1990; GUIEU, 1991). Results differ greatly according to methodology. Comparisons between estimates must be interpreted with caution, principally as a result of poor knowledge of elemental mass-size distributions (DULAC et al., 1989; MIGON et al., 1991; BUAT-MÉNARD, 1993). For example, in the NW Mediterranean, DULAC et al. (1989) proposed a theoretical dry deposition rate of $0.04 \mathrm{~cm} \mathrm{~s}^{-1}$ for Pb, while REMOUDAKI (1990) gave an experimental value of $1.9 \mathrm{~cm} \mathrm{~s}^{-1}$. Dry deposition rates are not well known for submicrometer particles (SLINN, 1983; ARIMOTO and DUCE, 1986), and difficulties increase when particle size exceeds $10 \mu \mathrm{m}$ : in this case, deposition rates are very high and their estimation becomes very questionable (DUCE et al., 1991). Moreover, phenomena such as fog or dew, which are common in coastal areas, significantly enlarge particles, thereby increasing their deposition rate (BERGAMETTI, 1987). Despite these problems, there is a significant amount of data on trace metal atmospheric fluxes, mainly for the Western and Central MED. They are listed in Tab. 2.3, which shows that the range of fluxes is quite high for some metals (e.g., $\mathrm{Al}, \mathrm{Cd}, \mathrm{Zn}$ ), and lower for others ( $\mathrm{Cu}, \mathrm{Pb}, \mathrm{Fe}, \mathrm{Ni})$ (GUIEU et al., 1997; GUERZONI et al., in press).

Tab. 2.3 - Range of total atmospheric fluxes (insoluble and soluble fractions), calculated from wet and dry deposition. 1=GUERZONI et al. (in press); 2=GUIEU et al. (1997).

\begin{tabular}{crrrr}
\hline & \multicolumn{2}{c}{ CMED $^{1}$} & \multicolumn{2}{c}{ NWMED $^{2}$} \\
umoles $\mathbf{~ m}^{-2} \mathbf{~ r r}^{-1}$ & insoluble & soluble & insoluble & soluble \\
\hline $\mathrm{Al}$ & $11250-33000$ & $330-890$ & $4900-31500$ & $370-3780$ \\
$\mathrm{Cd}$ & $0.1-0.3$ & $0.5-2.8$ & $0.9-3.6$ & $1.8-8.0$ \\
$\mathrm{Cu}$ & $50-70$ & $45-72$ & $22-30$ & $12-20$ \\
$\mathrm{Fe}$ & $2600-7300$ & $90-180$ & $12500-14500$ & $570-2500$ \\
$\mathrm{Ni}$ & $8-32$ & $17-24$ & $7-9$ & $7-9$ \\
$\mathrm{~Pb}$ & $5-38$ & $5-24$ & $6-11$ & $4-9$ \\
$\mathrm{Zn}$ & $46-76$ & $210-460$ & $15-1000$ & $15-1150$ \\
\hline
\end{tabular}

\subsection{Fate of trace metals in seawater}

The magnitude of air-to-sea fluxes of trace metals partly depends on their concentrations in the air. However, the fate of an atmospherically-transported trace metal, once deposited at the sea surface, depends on its thermodynamic speciation in seawater, its speciation in the parent aerosol, and the kinetics controlling any speciation change. Aerosol speciation may be assessed by determining the partitioning of trace metals between the following fractions: (i) exchangeable, the most mobile, (ii) oxide/carbonate, intermediate mobility, and (iii) refractory, the least mobile. The speciation of trace 
metals in aerosols is a function of the source of the aerosol since some trace metals have very different speciation signatures in anthropogenic-rich and crust-rich "end-member" MED aerosols (CHESTER et al., 1996), and chemical changes occur during passage and transformation in the atmosphere prior to deposition on the sea surface.

$\mathrm{Al}$ and $\mathrm{Fe}$ are generally refractory in both end-member aerosols, $\mathrm{Mn}$ is speciated between all three fractions in both end-member aerosols, but $\mathrm{Cu}, \mathrm{Zn}$ and $\mathrm{Pb}$ switch speciation signatures between the two end-member aerosols, being essentially refractory in crustal aerosols and exchangeable (i.e., mobile) in anthropogenic ones. Aerosols are removed from the air by dry fall-out and wet precipitation scavenging deposition modes.

In the dry mode, aerosols reach the sea surface directly and trace metal solubility is constrained by aerosol-sea water reactivity. There is a direct relationship between the extent to which a trace metal is soluble in seawater and the extent to which it is held in the exchangeable fraction of an aerosol (Fig. 2.1). For $\mathrm{Al}$ and $\mathrm{Fe}$ in both end-member aerosols, $<\sim 10 \%$ of their total concentrations is in the form of exchangeable associations and both are also relatively insoluble in seawater. However, since both metals are present in relatively high concentrations in aerosols ( $3-8 \%$ by weight), even a solubility of a few percent can release considerable quantities of $\mathrm{Al}$ and Fe to seawater in a dissolved form. Mn has between $\sim 20 \%$ and $\sim 50 \%$ of its total concentration in the exchangeable fraction of each end-member aerosol and is relatively soluble, with $\sim 35 \%-\sim 50 \%$ of the total amount from each phase dissolving. $\mathrm{Cu}$, $\mathrm{Zn}$ and $\mathrm{Pb}$ have significantly higher solubilities from the anthropogenic-rich than from the crust-rich end-member, due to their different speciation signatures in the two aerosol types. This is important, because it means that the aerosol seawater solubilities of $\mathrm{Cu}, \mathrm{Zn}$ and $\mathrm{Pb}$ are reduced when crust-rich Saharan inputs perturb the anthropogenic-rich background aerosol over the MED.
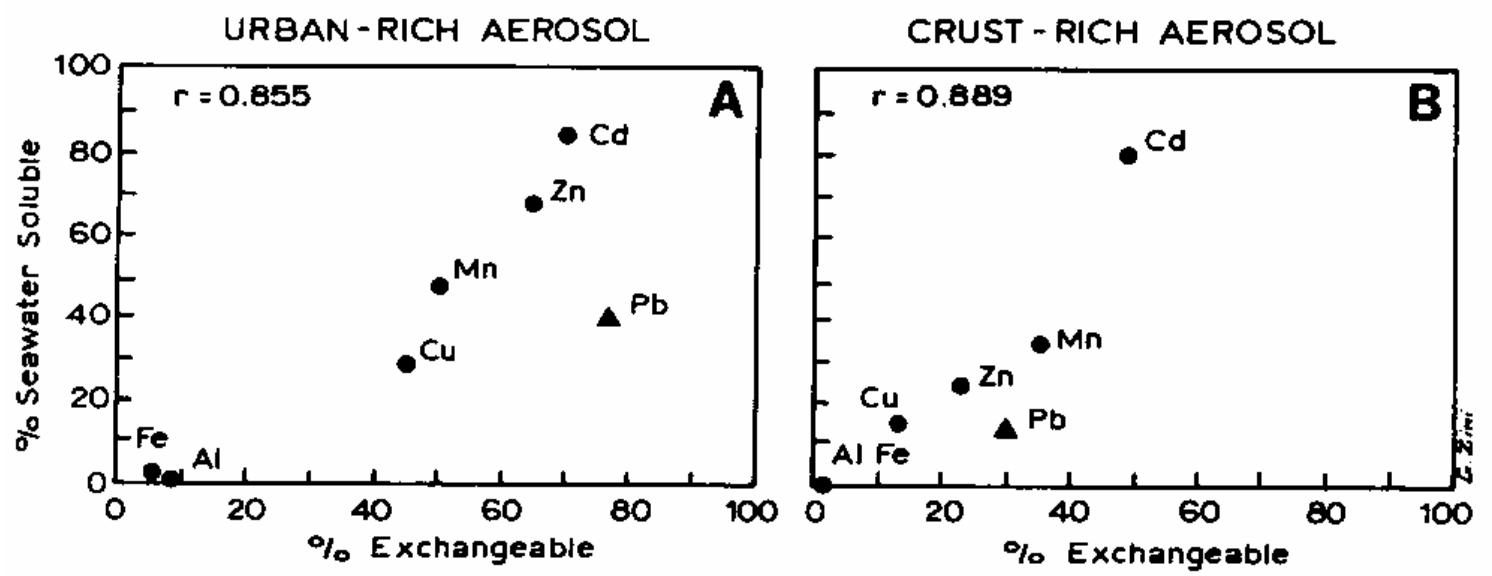

Fig. 2.1 - Relationship between percentages of total concentrations of trace metals soluble in seawater and in exchangeable associations in a) anthropogenic-dominated and b) crust-dominated aerosols. After CHESTER et al. (1993).

In the wet deposition mode, trace metal solubility is constrained initially by aerosol-rainwater reactivity since some metals are already in solution prior to the deposition of the aerosols on the sea surface. 
Solubility is still a function of trace metal speciation in the parent aerosol, as illustrated by the dissolved/particulate speciation of a number of trace metals in rainwater from Western Mediterranean sites (Tab. 2.4). Al and $\mathrm{Fe}$ are generally insoluble in all types of rainwater $(<20 \%$ of total concentrations), and $\mathrm{Cd}$ and $\mathrm{Mn}$ are relatively soluble (60-90\% of total aerosol). $\mathrm{Cu}, \mathrm{Zn}$ and $\mathrm{Pb}$ solubilities vary considerably from one rainwater sample to another and from site to site, e.g. that of $\mathrm{Pb}$ varies from $\sim 20 \%$ at Sardinia to $\sim 70 \%$ at Cap Ferrat.

Tab. 2.4 - Average dissolved/particulate speciation of trace metals in rainwaters from a number of Mediterranean Sea sites; data given as \% of total trace metal concentration in dissolved phase.

\begin{tabular}{ccccc}
\hline & Cap Ferrat $^{*}$ & Tour du Valat $^{*}$ & Sardinia\# & Corsica $^{*}$ \\
\hline $\mathrm{Al}$ & 18 & 19 & 2 & 8 \\
$\mathrm{Fe}$ & - & 11 & 3 & 13 \\
$\mathrm{Mn}$ & 60 & 63 & - & 67 \\
$\mathrm{Ni}$ & 54 & 58 & - & - \\
$\mathrm{Co}$ & 61 & 50 & - & - \\
$\mathrm{Cu}$ & 82 & 71 & - & 49 \\
$\mathrm{Zn}$ & - & 68 & - & 76 \\
$\mathrm{~Pb}$ & 65 & 52 & 21 & 48 \\
$\mathrm{Cd}$ & 92 & 75 & 75 & - \\
\hline
\end{tabular}

* GUIEU et al. (1997); \# GUERZONI et al. (1997)

The speciation and solubility of trace metals is strongly affected by rainwater $\mathrm{pH}$. Scavenging of anthropogenic-rich aerosols results in rainwater having $\mathrm{pH}$ values of $<\sim 4-5$. In contrast, the scavenging of Saharan dust, with relatively high carbonate content, yields rainwaters with $\mathrm{pH}$ values of $>\sim 5$. Many adsorption/desorption reactions are pH-dependent, particularly those affecting exchangeable trace metals. This may be illustrated for $\mathrm{Pb}$ in a series of rainwaters collected at Cap Ferrat (CHESTER et al., 1990). The most striking feature in the $\mathrm{pH}$ vs solubility plot for $\mathrm{Pb}$ is the presence of the classical $\mathrm{pH}$ adsorption edge (Fig. 2.2), which is typical of adsorption/desorption processes at particulate-water interfaces and has been studied by various authors, in both rain and aerosols (CHESTER et al., 1993; LIM et al., 1994; SPOKES and JICKELLS, 1996). For Pb, this adsorption edge lies in the $\mathrm{pH}$ region $\sim 4.8-\sim 5.8$. On the more acidic side, $\sim 80 \%$ of total $\mathrm{Pb}$ is in the soluble form, whereas on the alkaline side only $\sim 10 \%$ is soluble. However, some authors note that the low solubility region is defined by a relatively small number of points, reflecting the few cases studied of rain with pH >6 (LIM et al., 1994; SPOKES and JICKELLS, 1996). This observation is important, given that these waters normally contain variable amounts of particulate material and that particle concentrations, grain-size, and physical surface characteristics (scavenged clays or silicate mineral aerosol) may also be important parameters in adsorption models of trace metals in rain (LIM et al., 1994). In fact, aerosol dissolution experiments performed at particle concentrations ranging from 3 to $300 \mathrm{mg} \mathrm{I}^{-1}$ (the usual particle concentrations found in MED rainwater, see Tab.1.1) showed that $\mathrm{Cd}$ and $\mathrm{Pb}$ have low solubility at high particle concentrations (Fig. 2.3). The solubility of $\mathrm{Pb}$ was also found 
to increase with increasing $E F_{\text {crust }}$ values and with increasing content of the finest $(<1 \mu \mathrm{m})$ grain-size of the aerosols (GUERZONI et al., in press).

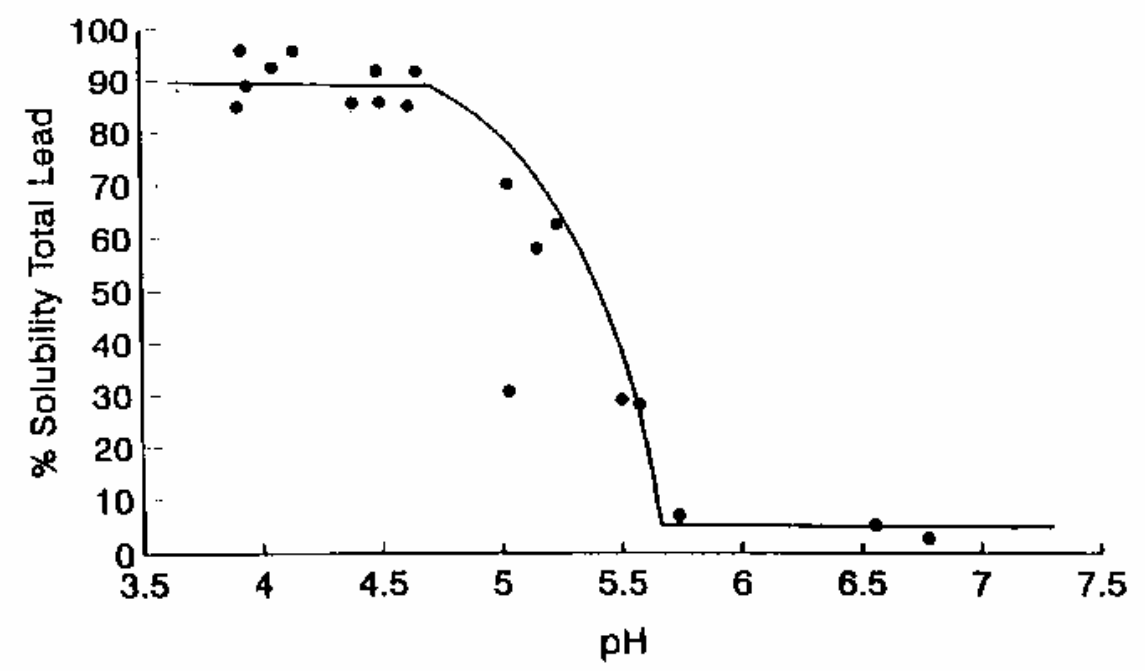

Fig. 2.2. - $\mathrm{pH}$ solubility of $\mathrm{Pb}$ in Western Mediterranean rainwaters (after CHESTER et al., 1990).

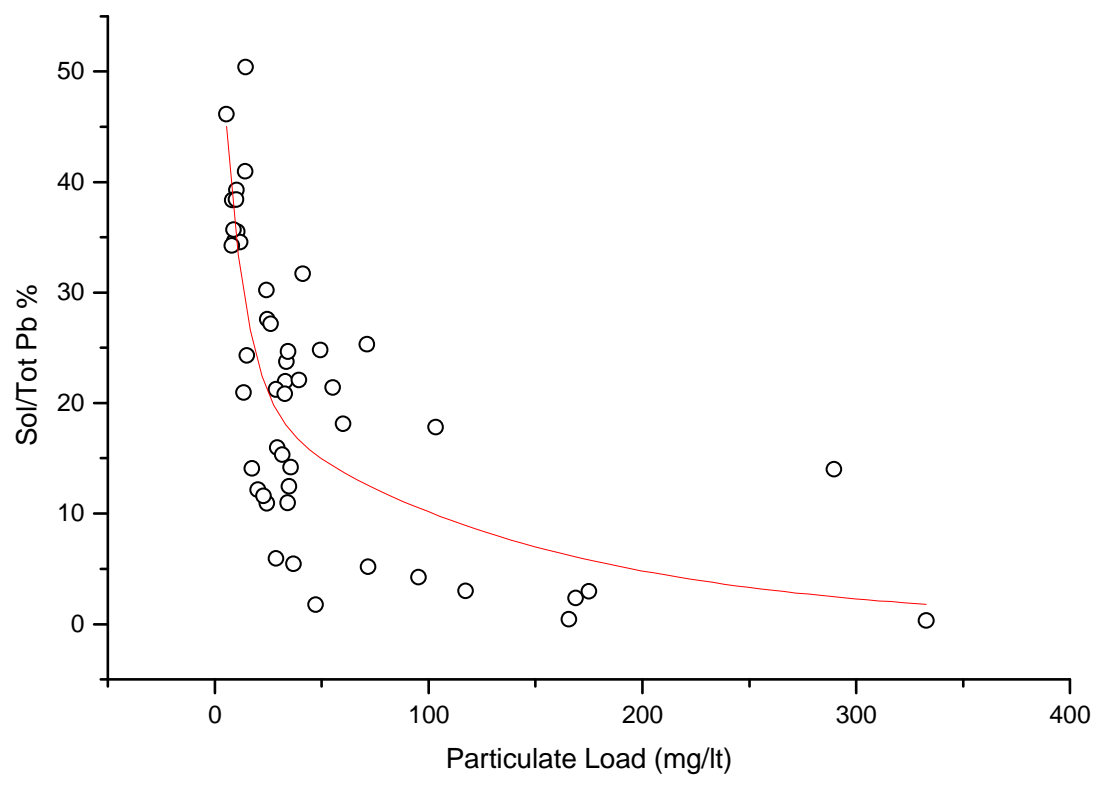

Fig. 2.3 - Lead solubility versus particulate load in aerosol dissolution laboratory experiment (from GUERZONI et al., in press). 


\subsection{Atmospheric versus riverine inputs}

Having identified atmospheric input as being important to the ocean, what problems remain in understanding the magnitude and significance of this input mode, with respect to riverine input? Aerosol undersampling problems may be remedied by increased sampling effort. Alternatively, atmospheric fluxes may be calculated from atmospheric transport and deposition models (ERDMAN et al., 1994), using information on emission source strength (NRIAGU and PACYNA, 1988; GESAMP, 1989; AXENFELD et al., 1992).

We present here two examples of comparison between riverine and atmospheric inputs using measurements made in the WMED and the Adriatic, Central Mediterranean (CMED).

\subsubsection{Measurements.}

The total atmospheric inputs of several trace elements and potential pollutants are compared with total riverine trace metal inputs for the Adriatic and the NW Mediterranean in Tab. 2.5.

Tab. 2.5 - Comparison between total inputs of atmospheric and riverine origin for Adriatic and NW Mediterranean (all data in ton $\mathrm{yr}^{-1}$ ). ${ }^{*} \mathrm{Al}$ and Fe: ton x 1000; \# Adriatic Sea area: $112,000 \mathrm{~km}^{2}$; from ROSSINI and GUERZONI (1996); § NW Mediterranean Sea area: $180,000 \mathrm{Km}^{2}$, from GUIEU et al. (1997).

\begin{tabular}{lcccccccc}
\hline & tons year $^{-1}$ & $\mathrm{Al}^{*}$ & $\mathrm{Fe}^{*}$ & $\mathrm{Cd}$ & $\mathrm{Pb}$ & $\mathrm{Cu}$ & $\mathrm{Ni}$ & $\mathrm{Zn}$ \\
\hline \multirow{2}{*}{ Adriatic $^{\#}$} & atmosphere & 29 & 14 & 18 & 311 & 489 & 148 & 177 \\
& Po river & 86 & 74 & 7 & 151 & 281 & 514 & 935 \\
\hline \multirow{2}{*}{ NW Med. } & atmosphere & 97 & 151 & 126 & 579 & 486 & 162 & 12,600 \\
& Rhône \& Ebro rivers & 441 & 232 & 13 & 318 & 505 & 450 & 1545 \\
\hline
\end{tabular}

The data indicate that the atmosphere supplies $16-90 \%$ of the total input of these elements. When dissolved fluxes are compared (the form most likely to impinge on surface water biogeochemical cycles), the influence of atmospheric input is even more pronounced (Tab. 2.6).

Tab. 2.6 - Comparison between dissolved inputs of atmospheric and riverine origin for Adriatic (area: 112,000 $\mathrm{km}^{2}$ ) and NW Mediterranean (area: 180,000 $\mathrm{Km}^{2}$ ). \# Adriatic Sea: from ROSSINI and GUERZONI (1996); § NW Mediterranean Sea: from GUIEU et al. (1997).

\begin{tabular}{lcccccccccc}
\hline & tons year $^{-1}$ & $\mathrm{Al}$ & $\mathrm{Fe}$ & $\mathrm{Cd}$ & $\mathrm{Pb}$ & $\mathrm{Cu}$ & $\mathrm{Ni}$ & $\mathrm{Zn}$ & $\mathrm{PAH}$ & $\mathrm{PCB}$ \\
\hline \multirow{2}{*}{ Adriatic $^{\#}$} & atmosphere & 1039 & 573 & 13 & 152 & 332 & 116 & 1560 & & \\
& Po river & 60 & 30 & 4 & 10 & 66 & 148 & 215 & & \\
\hline \multirow{2}{*}{ NW Med. ${ }^{\S}$} & atmosphere & 10 & 16 & 99 & 252 & 189 & 81 & 6813 & 45 & 12 \\
& Rhône \& Ebro rivers & 1 & 1 & 2 & 8 & 175 & 115 & 105 & 15 & 1 \\
\hline
\end{tabular}


For example the atmosphere is 5-50 times more important than rivers for dissolved $\mathrm{Zn}$ fluxes and 15 30 times more important for $\mathrm{Pb}$ fluxes. A similar pattern is seen for $\mathrm{Cu}$. The dramatic difference between total particulate and dissolved fluxes underscores the important role played by speciation of trace elements in rainwater in determining their flux to the surface ocean.

\subsubsection{Models.}

Only by using models can we extend the same comparison to each of the three basins of the MED (Tab. 2.7). This comparison is meant to show the same approach as the two tables above but is extended to other basins for total fluxes.

Table 2.7 - Comparison of total riverine $(R)$ and atmospheric $(A)$ inputs to Mediterranean Sea (all in tons $\mathrm{yr}^{-1}$ ). Data on $\mathrm{Pb}$ and $\mathrm{Zn}$ riverine inputs from UNEP (1984), on atmospheric input from ERDMAN et al. (1994) and GESAMP (1989).

\begin{tabular}{llrrrr}
\hline Sub-basin & $\begin{array}{c}\text { Area } \\
\left(10^{6} \mathrm{~km}^{2}\right)\end{array}$ & $\mathrm{R}$ & $\mathrm{A}$ & \multicolumn{2}{c}{$\mathrm{Zn}$} \\
\hline Western Med & 0.84 & 2200 & 3072 & 9200 & 1125 \\
Central Med & 0.80 & 1770 & 2757 & 10700 & 809 \\
Eastern Med & 0.70 & 850 & 1605 & 4800 & 590 \\
Total & & & & & \\
\% atmosphere & $\mathbf{2 . 3 4}$ & $\mathbf{4 8 2 0}$ & $\mathbf{7 4 0 4}$ & $\mathbf{2 4 7 0 0}$ & $\mathbf{2 5 2 4}$ \\
& & & 61 & & 9 \\
\hline
\end{tabular}

Available estimates of riverine and atmospheric inputs were computed on the basis of average pollutant concentrations and mean water discharges for rivers (UNEP, 1984) and by applying a Eulerian-Lagrangian model for atmospheric transport and deposition (ERDMAN et al., 1994).

Several sources of errors are associated with these estimates. An example is given in Tab. 2.8, showing a comparison between measured and model data for $\mathrm{Pb}$ and $\mathrm{Zn}$ in the Adriatic (equivalent to WMO area MT5; see ERDMAN et al., 1994) and north-western Mediterranean (equivalent to WMO area MT2; see ERDMAN et al., 1994). In these models, the authors state that the discrepancy between regional mean values for $\mathrm{Pb}$ does not exceed $20 \%$, but very often individual data are less reliable. For $\mathrm{Zn}$, the total underestimation of mean values by the models may be 10 times lower, mainly because of underestimation of the emission strength .

These comparisons of modelling results with measurement data for atmospheric deposition should only be considered as approximate, for the following reasons (EMEP, 1994): i) models give grid square (e.g. $150 \times 150 \mathrm{~km}$ ) average values and measurements give point values, and variations between measurement and model data increase with increasing grid size and decreasing averaging time; ii) as completeness of measurement data should be $75-80 \%$ over a rather long period of time (e.g., at least one month) to be used for comparison with modelling results, better spatial and temporal data rage is needed; iii) measurement sites should be representative for the whole grid square 
(meteorological conditions, surface characteristics, local pollution sources, etc.); iv) several monitoring sites are needed for a square of $150 \times 150 \mathrm{~km}$ and correlation analysis between sites should be applied, taking into account seasonality, mixing, time scale, meteorology, emission and topography; v) measurement and modelling data used for comparison purposes are sometimes made at different times (or even in different years) and the year-to-year variability of meteorological conditions introduces uncertainty into single-year model (or measurement) estimates; vi) emissions used for modelling are rather uncertain and sometimes underestimated, and are mainly based only on annual estimates from major sources without the required temporal and spatial distributions.

Tab. 2.8 - Comparison between atmospheric (measured and modelled) and riverine inputs (measured and estimated).

\begin{tabular}{|c|c|c|c|c|c|}
\hline Region & Input & & $\mathrm{Pb}$ tons $\mathrm{y}^{-1}$ & Zn tons $\mathrm{y}^{-1}$ & Reference \\
\hline \multirow{2}{*}{ Adriatic } & atmospheric & $\begin{array}{l}\text { measured } \\
\text { model }\end{array}$ & $\begin{array}{l}311 \\
871\end{array}$ & $\begin{array}{l}177 \\
246\end{array}$ & $\begin{array}{l}\text { ROSSINI and GUERZONI (1996) } \\
\text { ERDMAN et al. (1994) }\end{array}$ \\
\hline & riverine & $\begin{array}{l}\text { Po river } \\
\text { measured } \\
\text { estimated }\end{array}$ & $\begin{array}{c}151 \\
1300\end{array}$ & $\begin{array}{c}935 \\
7900\end{array}$ & $\begin{array}{l}\text { ROSSINI and GUERZONI (1996) } \\
\text { UNEP (1984) }\end{array}$ \\
\hline \multirow{2}{*}{ NW Med } & atmospheric & $\begin{array}{l}\text { measured } \\
\text { model }\end{array}$ & $\begin{array}{l}579 \\
999\end{array}$ & $\begin{array}{c}12600 \\
337\end{array}$ & $\begin{array}{l}\text { GUIEU et al. (1997) } \\
\text { ERDMAN et al. (1994) }\end{array}$ \\
\hline & riverine & $\begin{array}{l}\text { Rhône \& Ebro } \\
\text { measured } \\
\text { estimated }\end{array}$ & $\begin{array}{l}318 \\
800\end{array}$ & $\begin{array}{l}1545 \\
2400\end{array}$ & $\begin{array}{l}\text { GUIEU et al. (1997) } \\
\text { UNEP (1984) }\end{array}$ \\
\hline
\end{tabular}

It may be seen that atmospheric data are in agreement within a factor of 2-3, whereas huge differences are evident for riverine inputs. Some of these differences are due to the reduction in run-off and discharge over the last 10-20 years, not always accounted for in the models. Furthermore, riverine model data are derived from run-off estimates and contain few real measurements, therefore providing only an order-of-magnitude estimate of the elemental input for the MED basin. In addition, the differences between models and measured data may be due to the behaviour of elements in estuarine areas. The chemical behaviour of elements in this zone is very difficult to generalise. For some elements there is removal from the water column in the estuarine zone while for others there is no effect. In some cases (e.g. Cd), there is addition of the element to the dissolved phase as a result of the competitive desorption of $\mathrm{Cd}$ bound to the surface of suspended particulate material by seawater ions. While the behaviour of a particular element can be characterised in a particular estuary, different physico-chemical regimes (e.g. $\mathrm{pH}$, ionic strength, presence of dissolved organic matter, etc.) in a different estuary can lead to different behaviour in the mixing zone.

\subsection{Case studies.}

2.5.1. The atmospheric "signature" in seawater. For some reactive trace elements including $\mathrm{Al}, \mathrm{Mn}$ and most notably Pb (BRULAND et al., 1991; BUAT-MENARD, 1993; PATTERSON and SETTLE, 1987), 
the shapes of dissolved oceanic profiles with surface water concentration maxima suggest that atmospheric input is of major importance. For other elements which are not so rapidly removed from seawater by scavenging processes, internal biogeochemical cycles mask such input signals.

$\mathrm{Al}$ and $\mathrm{Fe}$. It has been shown above that $\mathrm{Al}$ and $\mathrm{Fe}$ have only relatively low solubilities from aerosols but, since they are present in large concentrations, even low solubility can deliver significant quantities to the dissolved seawater pool from dust pulses.

The effect of dust deposition of Al on MED surface waters is dramatically visible in its effect on the surface water concentrations. The extremely high concentration of this element in crustal materials (8.1\%; TAYLOR, 1964), and its low concentration in seawater makes it a particularly good tracer of the partial dissolution of eolian dust in MED surface waters. In fact, as a result of biological and convective transport, the deep waters of the MED have the highest concentrations of dissolved Al of any basin in the world, consistent with their receiving the greatest rate of deposition of eolian material. The effect that this has on the Al budget has been recognised by several workers (HYDES et al., 1988; MEASURES and EDMOND, 1988; CHOU and WOLLAST, 1997), the latter indicating that the partial deposition of eolian dust in the WMED was responsible for some 20 times as much input of $\mathrm{Al}$ as that supplied by rivers. That the eolian input is basin-wide is shown by the progressive build-up of Al from west to east along the advective flow path of the incoming Atlantic surface water (Fig. 2.4).

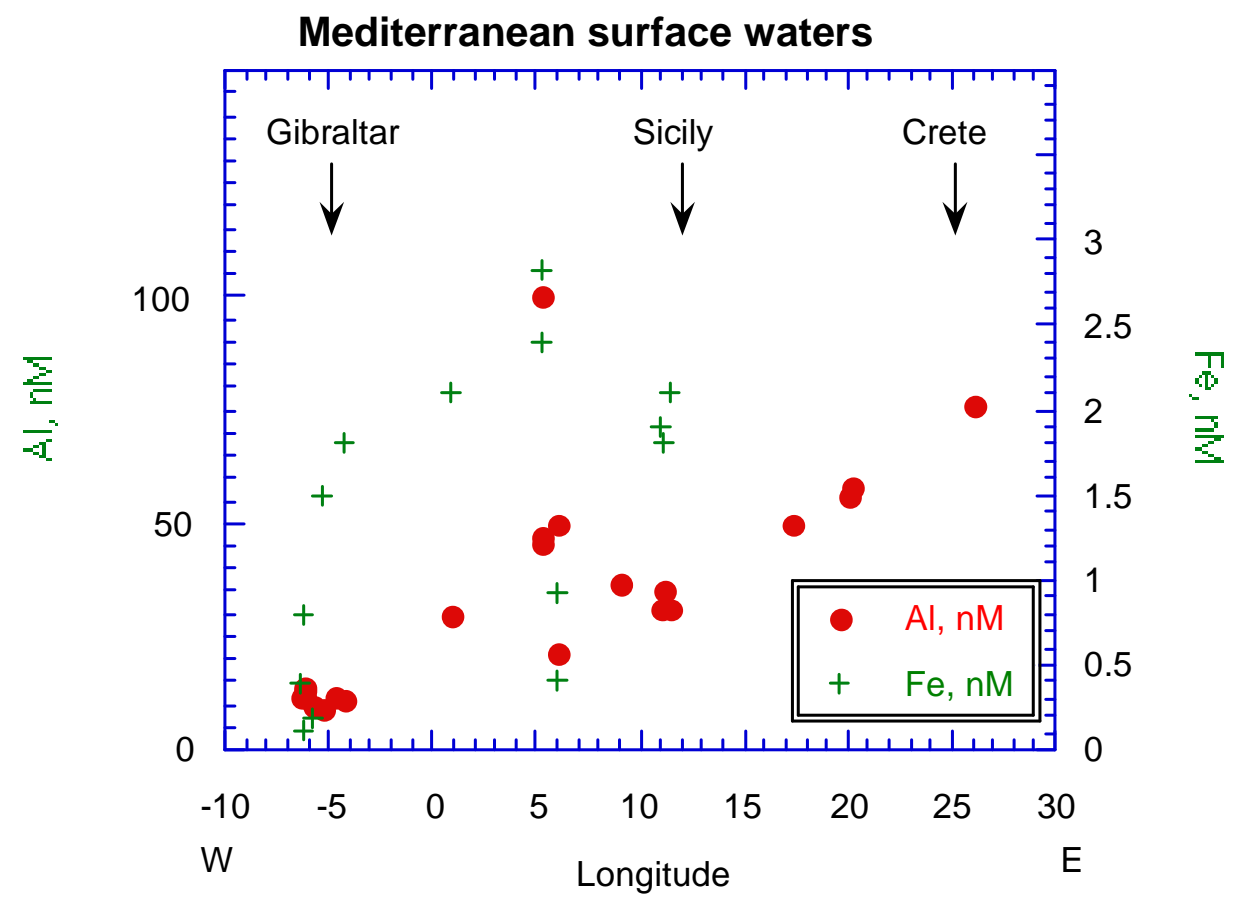

Fig. 2.4 - Distributions of dissolved Al and Fe in surface waters of Mediterranean. 
In this figure, all post-1980 surface water Al values in the open Mediterranean are plotted as a function of longitude. Data from the region of the Gulf of Lions are excluded, to eliminate the local influence of the Rhone discharge. In addition, early Corsican nearshore data are excluded, to eliminate local artifacts.

The data distribution is quite distinctive in that there is an unmistakable increase in Al concentrations from 9-13 $\mathrm{nM}$ at the Strait of Gibraltar $(6 \mathrm{~W})$ to $\sim 75 \mathrm{nM}$ at $26 \mathrm{E}$ in the eastern basin. The anomalously high value at $\sim 5 \mathrm{E}(100 \mathrm{nM})$ results from elevated deep water mixing into the surface waters in December 1988, during a convection episode in the Western Mediterranean Deep Water formation region. The general trend indicates something of the order of a 60-nM Al enrichment of inflowing Atlantic surface waters during their eastward transit from the Strait of Gibraltar to the eastern basin. The magnitude of this Al enrichment may be compared with estimates of atmospheric deposition to the region. GUIEU et al. (1997), using atmospheric data from coastal collection sites, estimated an annual deposition of some 0.38 to 3.8 mmoles of dissolved $\mathrm{Al} \mathrm{m}^{-2}$ to the surface waters of the north-west Mediterranean. Such an input into a 50-m mixed layer, over the advective flow path of the Atlantic water, could easily raise Al concentrations in inflowing surface water to the values seen in the eastern basin over the time-scales of surface water renewal in the Mediterranean (1-10 years).

While the impact of dust is readily observed and is quantified in the Al signal, its effect on $\mathrm{Fe}$ concentrations is more difficult to quantify. The largest problem is the small data base of reliable measurements for Fe in the Mediterranean. Fig. 2.4 plots all the surface water dissolved Fe data of MORLEY et al. (1997) available in the EROS-2000 data base which appear to be oceanographically consistent. The data of MORLEY et al. (1997) show a wide range of concentrations from $0.11 \mathrm{nM}$ in the Strait of Gibraltar to $2.83 \mathrm{nM}$ south of the Gulf of Lions. However, unlike the Al, there is no clear geographic trend associated with these values. Nevertheless, it may be stated that, on the basis of this data set, Fe levels are generally above $1 \mathrm{nM}$ within the Mediterranean. It therefore seems reasonable to conclude that Fe cannot be considered as limiting factor to phytoplankton. This appears to be probable merely on the basis of available nutrients. Since the surface Mediterranean is low in nutrients, Fe demand is similarly low. Using Fe limiting conditions and assuming a $\mathrm{C}: \mathrm{N}$ ratio of 6.7, $0.5 \mathrm{nM}$ of $\mathrm{Fe}$ (at the low end of the observed amount of $\mathrm{Fe}$ in 1-L of seawater) is capable of removing $7.5 \mu \mathrm{M}$ of $\mathrm{N}$ from surface waters, an extremely large amount of $\mathrm{N}$ to be found in $1-L$ of seawater in this nutrient-impoverished sea.

In summary, dust input to the Mediterranean clearly affects surface water trace element budgets, and this is most visible for Al for which a large data base of modern observations exists. Although surface water Fe concentrations in the Mediterranean also appear elevated, the small size and geographical extent of the existing data base precludes direct association of these values with dust deposition events. It is unlikely that dust deposition to the surface Mediterranean would spur primary production through either the relief of Fe-limiting conditions or the provision of a bioactively reduced Fe species. 
2.5.2. $\mathrm{Pb}$ in atmosphere and seawater. The EROS 2000 data base on lead concentrations over the period 1989-1993 gave an average of 100pM in surface waters and $80 \mathrm{pM}$ in bottom waters. A mass balance for the WMED has been computed (MILLIMAN and MARTIN, 1997), and the output/input ratio for lead in the whole basin is 0.8 , with a residence time of 5.2 years (water residence time being $\sim 15$ years). A tentative budget of dissolved lead in the WMED (WOLLAST, pers. comm.) indicates an accumulation in the water of 440 tons $\mathrm{yr}^{-1}$ for the period 1970-1985, related to the constant increment in consumption of leaded gasoline in that period.

In contrast, a recent paper (MIGON and NICOLAS, 1998) shows a reduction (over the period 19871995) of atmospheric fluxes of dissolved $\mathrm{Pb}$ from 3.5 to $1.5 \mathrm{mg} \mathrm{m}^{-2} \mathrm{yr}^{-1}$, and of surface water concentrations in the WMED (central Ligurian Sea) from 300 to $120 \mathrm{pM}$. The amount of $\mathrm{Pb}$ in inflowing rivers has probably decreased in a similar way to the atmospheric input. However: i) the natural $\mathrm{Pb}$ component is probably higher in rivers than in the atmosphere, because of soil erosion; ii) a previous study (MIGON, 1993) showed that riverine $\mathrm{Pb}$ fluxes are far lower than atmospheric ones, and the loss of atmospheric $\mathrm{Pb}$ was estimated at $>90 \%$; iii) $\mathrm{Pb}$ dissolved in fresh water tends to precipitate and settle close to the river mouth (SHARP and NARDI, 1987; WINDOM et al., 1988; DORTEN et al., 1991), which lowers the role of the riverine contribution to offshore marine $\mathrm{Pb}$ concentrations. These results confirm the importance of the atmosphere in delivering $\mathrm{Pb}$ to surface waters and in controlling its concentration. Figure 2.5 illustrates the temporal evolution of dissolved $\mathrm{Pb}$ concentrations in surface waters (upper $100 \mathrm{~m}$ ), together with mean atmospheric fluxes. The two curves have the same shape, which a posteriori indicates that the introduction of automotive $\mathrm{Pb}$ into the marine environment essentially occurs through the atmospheric pathway.

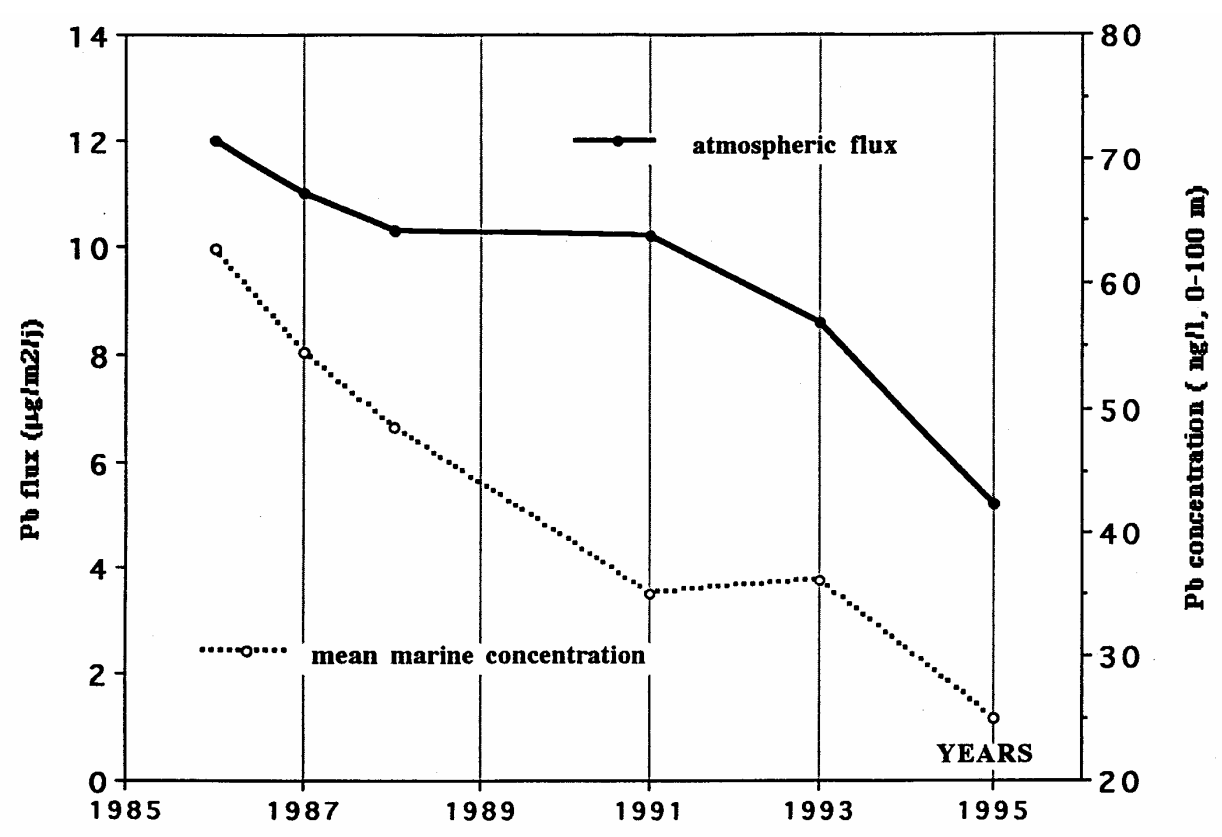

Fig. $2.5-\mathrm{Pb}$ atmospheric flux and mean marine $\mathrm{Pb}$ concentrations $(0-100 \mathrm{~m})$ (from MIGON and NICOLAS, 1998). 


\section{Atmospheric input of nutrients: estimates and impacts}

The importance of the atmosphere as a source of nutrients, especially nitrogen, for terrestrial ecosystems was recognised as a by-product of studies of the impact of acid rain in the early 1980s. At the end of that decade, atmospheric nitrogen deposition to marine systems began to be investigated and its importance for the global ocean was assessed (DUCE, 1986). For example, it has been noted that the atmospheric input of nitrogen may be partly responsible for the eutrophication of estuarine or coastal waters and the appearance of harmful algal blooms, by either direct input or through the watershed (FISHER et al., 1988; MALLIN et al., 1993; PAERL et al.,1993).

Despite early observations of $P$ limitation (FIALA et al., 1976; BERLAND et al., 1973, 1980), recent works suggest that MED surface waters are nitrogen-limited (ANDERSEN and NIVAL, 1988; OWENS et al., 1989). In fact, there is growing evidence that the EMED is phosphorus-limited (KROM et al.,1991) and that the WMED is probably N-limited (RAIMBAULT and COSTE, 1990; THINGSTAD and RASSOULZADEGAN, 1995), or that limitation shifts from nitrogen to phosphorus and vice versa depending on the period of the year (FIALA et al., 1976, DOLAN et al., 1995) or the area considered (WOODWARD and OWENS, 1989). The unique high levels of N/P ratios in the MED (20/27) compared with other open ocean averages (15) may reflect this situation, and are probably evidence of $P$ limitation.

\subsection{Atmospheric inputs of nitrogen to the Mediterranean}

While there are many natural sources of fixed nitrogen to the atmosphere - $\mathrm{NO}_{3}$ from soils and $\mathrm{NH}_{3}$ from wetlands - in the northern hemisphere the main sources are anthropogenic $\left(\mathrm{NO}_{\mathrm{x}}\right.$ from industrial combustion and vehicle traffic, $\mathrm{HNO}_{3}$ from vehicle traffic, $\mathrm{NH}_{3}$ emissions from intensive farming). The most abundant data are for inorganic wet deposition. Data for the WMED and EMED are listed in Table 3.1.

Tab. 3.1 - Dissolved inorganic nitrogen (DIN) wet deposition (a: LOŸE-PILOT et al., 1990a; b: MIGON et al., 1989; c: LOŸE-PILOT et al., 1990b; d: GUERZONI et al., 1993; e: LE BOLLOCH and GUERZONI, 1995; f: HERUT and KROM, 1996).

\begin{tabular}{|c|c|c|c|c|c|c|c|}
\hline \multirow[b]{2}{*}{ Studied site } & \multicolumn{2}{|c|}{ Field data } & \multicolumn{3}{|c|}{$\begin{array}{c}\text { Best estimates } \\
\text { in sub-basins }\end{array}$} & \multicolumn{2}{|c|}{ Mediterranean } \\
\hline & Period & $\begin{array}{c}\text { Range } \\
\text { (annual basis) } \\
\mu \mathrm{mol} m^{-2} d^{-1}\end{array}$ & NWME & VMEI & EMED & $\begin{array}{r}\text { Medit } \\
\mu m o l m^{-2} d\end{array}$ & $\begin{array}{l}\text { rranean } \\
10^{10} \mathrm{~mol}^{-1} \mathrm{r}^{-1}\end{array}$ \\
\hline $\begin{array}{l}\text { French coast - Camargue }{ }^{a} \\
\text { French coast - Cap Ferrat }^{b} \\
\text { Corsica - Bavella }^{c} \\
\text { Sardinia - C.Carbonara }^{d} \\
\text { Sardinia - Torregrande } \\
\text { Israel - Haifa+ South-EMED }^{e}\end{array}$ & $\begin{array}{c}\text { feb } 88 / \text { jul } 89 \\
86 / 87 \\
84 / 86 \\
91 / 94 \\
92 / 93 \\
92 / 95\end{array}$ & $\begin{array}{c}73 \\
119 / 142 \\
126 / 150 \\
47 \\
41 / 56 \\
65\end{array}$ & 100 & 80 & 50 & 50 / 80 & $\begin{array}{l}2,5 / 7,5 \\
4,6 / 7,3\end{array}$ \\
\hline
\end{tabular}


Atmospheric input of wet inorganic nitrogen. The average wet dissolved inorganic nitrogen (DIN) flux to

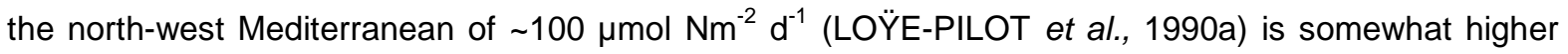

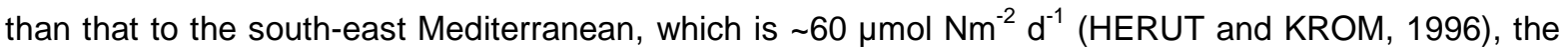

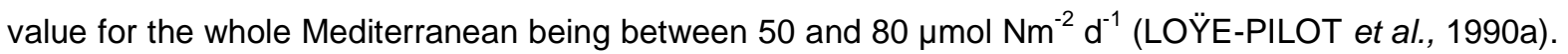
Nitrate and ammonium contribute almost equally to the DIN, while nitrite is normally less than $3 \%$.

Atmospheric input of dry inorganic nitrogen. Dry deposition of inorganic nitrogen includes gas and particulate deposition. Only annual average data are available for atmospheric particulate inorganic nitrogen species. Values in the NWMED are 1.71 and $0.85 \mu \mathrm{g} \mathrm{m}^{-3}$ for $\mathrm{NO}_{3}^{-}$and $\mathrm{NH}_{4}{ }^{+}$, respectively (KLEIN, 1998), and in the EMED 1.51 and $0.97 \mu \mathrm{g} \mathrm{m}{ }^{-3}$ for $\mathrm{NO}_{3}{ }^{-}$and $\mathrm{NH}_{4}{ }^{+}$(MIHALOPOULOS et al., 1997). These coastal values are in good agreement with the mean concentrations of 1.45 and $1.22 \mu \mathrm{g}$ $\mathrm{m}^{-3}$ for $\mathrm{NO}_{3}{ }^{-}$and $\mathrm{NH}_{4}{ }^{+}$obtained by MEDINETS (1996) from shipboard sampling over the whole Mediterranean. The reported values for particulate dry deposition depend on the deposition velocities chosen for $\mathrm{NO}_{3}{ }^{-}$and $\mathrm{NH}_{4}{ }^{+}$, the best estimate for the NWMED being $25 \mu \mathrm{mol} \mathrm{N} \mathrm{m}{ }^{-2} \mathrm{~d}^{-1}$ (KLEIN, 1998).

Gas concentration measurements are very scarce, especially for $\mathrm{NH}_{3}$ which is assumed to be negligible regarding $\mathrm{N}$ deposition to the Mediterranean. The few $\mathrm{HNO}_{3 \text { gas }}$ measurements are from urban sites.

Fig. 2.6 shows the partitions of various inorganic species and forms in the atmospheric deposition of nitrogen for the NWMED.

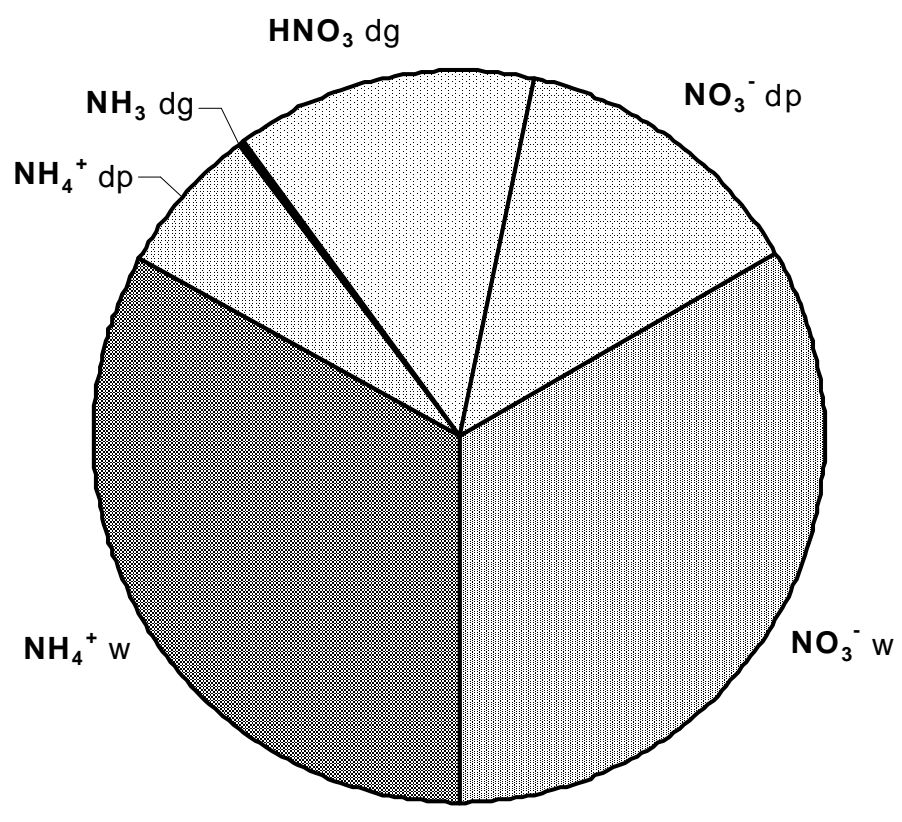

Fig. 2.6 - Relative importance of atmospheric inputs of different $\mathrm{N}$ species to NW

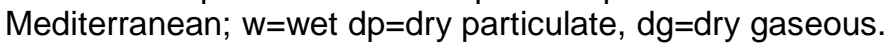


Total inorganic nitrogen deposition (Table 3.2). If only particulate dry species are taken into account, nitrogen dry deposition represents $25-33 \%$ of wet deposition in the north-west basin (LOŸE-PILOT et al., 1990, KLEIN, 1998); taking $\mathrm{HNO}_{3 \text { gas }}$ into consideration would increase the influence of dry deposition to equal wet deposition in coastal urbanised zones. Dry deposition equal to half that of wet deposition seems to be a realistic assessment for the open sea. Results are summarised in Table 3.2, which also lists data from the UNEP Mediterranean Pollution (MED POL) Project (computed from models) for 1991 (ERDMAN et al., 1994; UNEP, 1984). Total inorganic nitrogen deposition varies between $214 \mu \mathrm{mol} \mathrm{N} \mathrm{m} \mathrm{m}^{-2} \mathrm{~d}^{-1}$ for the Adriatic to about $48 \mu \mathrm{mol} \mathrm{N} \mathrm{m} \mathrm{d}^{-1}$ for the Central Mediterranean (UNEP zone VII) (ERDMAN et al., 1994), agreeing well with the previously estimated values of 105 $\mu \mathrm{mol} \mathrm{N} \mathrm{m}^{-2} \mathrm{~d}^{-1}$ for the WMED and $65 \mu \mathrm{mol} \mathrm{N} \mathrm{m} \mathrm{N}^{-2}$ for the EMED (LOŸE-PILOT et al., 1990b).

Distance from the source and climatological conditions appear to be the major factors which control

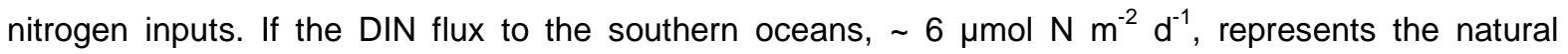
background level, then $90 \%$ of the total DIN flux into the Mediterranean is of anthropogenic origin.

Tab. 3.2 -Total nitrogen deposition (a: LOŸE-PILOT et al., 1993, b: KLEIN, 1998, c: LOŸE-PILOT, 1998, d: ERDMAN et al., 1994); $\mathrm{p}=$ particulate, $\mathrm{g}=$ gaseous species.

\begin{tabular}{|c|c|c|c|c|c|}
\hline & \multicolumn{5}{|c|}{ Best estimates } \\
\hline & \multirow{2}{*}{$\begin{array}{l}\text { NWMED } \\
\mu \mathrm{mol} \mathrm{m}^{-2} d^{-1}\end{array}$} & \multirow{2}{*}{$\begin{array}{c}\text { WMED } \\
\mu \mathrm{mol} \mathrm{m}^{-2} d^{-1}\end{array}$} & \multirow{2}{*}{$\begin{array}{c}\text { EMED } \\
\mu \mathrm{mol} \mathrm{m}^{-2} d^{-1}\end{array}$} & \multicolumn{2}{|c|}{ Mediterranean } \\
\hline & & & & $\mu \mathrm{mol} m^{-2} d^{1}$ & $10^{10} \mathrm{~mol} \mathrm{yr}^{-1}$ \\
\hline Field data & & & & & \\
\hline dryp $=1 / 3$ wet $^{a, b}$ & 125 & 105 & 65 & 65 / 105 & $5,6 / 9,0$ \\
\hline dryp $+g=1 / 2 w^{c} t^{c}$ & 150 & 120 & 75 & 75 / 120 & $6,4 / 10,2$ \\
\hline Model & & & & & \\
\hline$(\text { UNEP MAP 94) })^{d}$ & 117 & 107 & $\begin{array}{c}80 \\
\text { without Adriatic: } \\
69\end{array}$ & 89 & 7,6 \\
\hline
\end{tabular}

Organic nitrogen. The importance of organic nitrogen in total atmospheric nitrogen deposition has recently been re-evaluated; it may represent half of the input of inorganic forms on a regional scale and be equal to them for global ocean (CORNELL et al., 1995; DUCE et al., 1997). The source of organic nitrogen is not known, but CORNELL et al. (1995) believe that a large fraction of it is anthropogenic.

The few measurements of organic nitrogen content in the Mediterranean atmosphere (SPITZY et al., 1990; LOŸE-PILOT et al., 1992) indicate that total amino acid concentrations in aerosols and rainwater are small $(<5 \%)$ relative to inorganic species. It is clear that further studies are needed to assess the content, speciation and bioavailability of organic nitrogen in general and in the Mediterranean atmosphere in particular.

3.1.1. Atmospheric versus riverine inputs of nitrogen in the Mediterranean. The DIN atmospheric input to the NWMED is in the same range as the Rhone input, which is the major water and nutrient riverine output to the WMED. If the entire WMED is considered (LOŸE-PILOT et al., 1990b), then atmospheric 
input - derived from field data - is probably higher than that of rivers. Atmospheric input of $\mathrm{N}\left(1084 \times 10^{3}\right.$ tons $\left.\mathrm{yr}^{-1}\right)$ is equal to the riverine input $\left(1000 \times 10^{3}\right.$ tons $\left.\mathrm{yr}^{-1}\right)$ for the whole Mediterranean according to UNEP/WMO estimations (BASHKIN et al., 1997), the atmospheric input being predominant in the southern zones. If the fraction of riverine input which is derived from the atmosphere is taken into account, the atmospheric input is $\sim 60 \%$ of the total continental supply of nitrogen to the Mediterranean (BASHKIN et al., 1997).

Due to the fact that riverine nutrients are removed by biological activity in estuarine and proximal coastal zones, atmospheric input is probably the main source of nitrogen for the open sea, even in the northern zones of the Mediterranean.

3.1.2. Impact of atmospheric input of nitrogen on primary production. Atmospheric input of $\mathrm{N}$ contributes to new production (DUGDALE and GOERING, 1967; EPPLEY and PETTERSON, 1979; DUCE, 1986), which is the primary production fuelled by nutrients originating outside the photic zone, as opposed to production fuelled by recycled nutrients from within the photic zone. Assuming that the assimilation of nitrogen is in the Redfield ratio to carbon (16/106), then the atmospheric input of nitrogen may account for new production of about $3.8 \mathrm{~g} \mathrm{C} \mathrm{m}^{-2} \mathrm{y}^{-1}$ in the NWMED, $2.5 \mathrm{~g} \mathrm{C} \mathrm{m}^{-2} \mathrm{y}^{-1}$ in the SWMED, and $2.1 \mathrm{~g} \mathrm{C}$ $\mathrm{m}^{-2} \mathrm{y}^{-1}$ in the SEMED.

For coastal zones such as the Gulf of Lions, where total primary production is as high as $130-180 \mathrm{~g} \mathrm{C}$ $\mathrm{m}^{-2} \mathrm{y}^{-1}$ (MOREL et al., 1990; TUSSEAU and MOUCHEL, 1995) and new production is approximately one-third of the total, then the atmospheric input of nitrogen represents only about $6-10 \%$ of new production, while the Rhône river provides $\sim 50 \%$. However, in oligotrophic zones in the WMED, primary production is about $50 \mathrm{~g} \mathrm{C} \mathrm{m}^{-2} \mathrm{y}^{-1}$ and new production is as low as $5 \mathrm{~g} \mathrm{C} \mathrm{m}^{-2} \cdot \mathrm{yr}^{-1}$. In this case, the atmospheric $\mathrm{N}$ input of $2.5-3 \mathrm{~g} \mathrm{C} \mathrm{m}^{-2} \mathrm{y}^{-1}$ represents up to $60 \%$ of new production. This contribution is somewhat lower in the oligotrophic zones of the EMED, where new production has recently been reestimated at $16.7 \mathrm{~g} \mathrm{C} \mathrm{m}^{-2} \mathrm{y}^{-1}$ (KROM et al., 1991). In this case, the atmospheric input of nitrogen, $2.1 \mathrm{~g}$ $\mathrm{C} \mathrm{m}^{-2} \mathrm{y}^{-1}$, represents $\sim 12 \%$ new production.

\subsection{Atmospheric input of phosphorus}

The atmospheric input of phosphorus has received less attention than that of $\mathrm{N}$, as it is assumed to be less important. The atmospheric input of dissolved inorganic phosphorus to Cap Ferrat is estimated at $1.4 \mu \mathrm{mol} \mathrm{m} \mathrm{m}^{-2} \mathrm{~d}^{-1}$ and to be between 0.4 and $1.4 \mu \mathrm{mol} \mathrm{m}^{-2} \mathrm{~d}^{-1}$ for the NWMED (MIGON et al., 1989). Total inorganic phosphorus deposition to the WMED was determined to be $3.5 \mu \mathrm{mol} \mathrm{m} \mathrm{m}^{-2} \mathrm{~d}^{-1}$ from 3 years of samples collected in Corsica. Crustal material made up $40 \%$ of this flux, and the dissolved fraction was estimated to be between one- and two-thirds of the total (BERGAMETTI et al., 1992).

The wet deposition of total inorganic phosphorus to the SEMED, estimated from 2 years of measurements on the northern coast of Israel was $0.6 \mu \mathrm{mol} \mathrm{m}^{-2} \mathrm{~d}^{-1}$ and dry deposition was $1.2 \mu \mathrm{mol} \mathrm{m}{ }^{-2}$ $\mathrm{d}^{-1}$ (HERUT and KROM, 1996), giving a total rate of $1.8 \mu \mathrm{mol} \mathrm{m}^{-2} \mathrm{~d}^{-1}$. 


\subsubsection{Saharan dust and phosphorus.}

Phosphorus values of Saharan dust range from $0.04 \%$ found in the SEMED to $0.07 \%$ from Libyan desert material (HERUT and KROM, 1996). Values as high as 0.25-0.40\% were found in Saharan dust collected in the NWMED (LOŸE-PILOT, unpublished results). A mean content of $0.25 \%$ gives a mean phosphorus deposition from Saharan dust in this region of $2.8 \mu \mathrm{mol} \mathrm{m} \mathrm{m}^{-2}$. However, the question of the solubility and bioavailability of this phosphorus is still open. According to KROM et al., (1991), Saharan dust may act as a trap for soluble phosphorus by adsorption of $\mathrm{PO}_{4}{ }^{3-}$ on to Fe-rich particles, whereas LEPPLE, (1971) found that up to $8 \%$ of Saharan dust phosphorus is soluble in seawater. From a partitioning study between crustal and anthropogenic phosphorus, BERGAMETTI et al., (1992) estimated that between 1.2 and $2.7 \mu \mathrm{mol} \mathrm{P} \mathrm{m}{ }^{-2} \mathrm{~d}^{-1}$ is dissolved in seawater from atmospheric input and

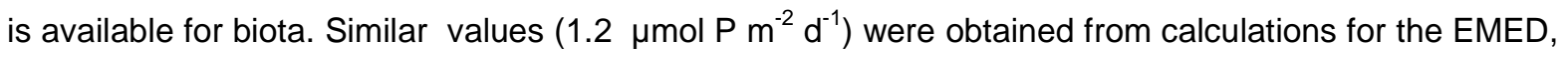
assuming a dust flux of $36 \mathrm{~g} \mathrm{~m}^{-2} \mathrm{yr}^{-1}$, with $0.4 \% \mathrm{P}$ and a solubility in seawater of $10 \%$ (see section 4.1 ). Table 3.3 shows estimates of the dissolved inorganic phosphorus (DIP) inputs to the WMED (1.5 $\mu \mathrm{M} P$ $\left.\mathrm{m}^{-2} \mathrm{yr}^{-1}\right)$ and EMED $\left(0.6 \mu \mathrm{M} \mathrm{P} \mathrm{m}{ }^{-2} \mathrm{yr}^{-1}\right)$, and Table 3.4 compares total inorganic phosphorous (TIN) atmospheric inputs with riverine $\mathrm{P}$ discharge estimates.

Tab. 3.3 - Dissolved inorganic phosphorus (DIP) and total inorganic phosphorus (TIP) deposition (values in $\mu \mathrm{mol} \mathrm{m}^{-2} \mathrm{~d}^{-1}$ ).

\begin{tabular}{|c|c|c|}
\hline & DIP & TIP \\
\hline Cap Ferrat $^{a}$ & 1.4 & -- \\
\hline NWMED ${ }^{b}$ & $0.4-1.4$ & $\overline{35}$ \\
\hline Corsica $^{c}$ & $1.2-2.7$ & $\begin{array}{c}3.5 \\
\text { (2.1 anthro+1.4 Sahara) }\end{array}$ \\
\hline $\begin{array}{l}\text { Corsica }^{d} \\
\text { avg. WMED }\end{array}$ & $\begin{array}{l}-- \\
1.5\end{array}$ & $\begin{array}{l}\text { 2.8 Sahara } \\
3\end{array}$ \\
\hline EMED $^{e}$ & 0.6 & $\begin{array}{c}1.8 \\
\left(0.021 \mathrm{gP} \mathrm{m}^{-2} \mathrm{yr}^{-1}\right)\end{array}$ \\
\hline
\end{tabular}

a, b: MIGON (1989); c: BERGAMETTI et al. (1992); d: LOŸE-PILOT, unpublished results; e: HERUT and KROM (1996)

Table 3.4 - Comparison of riverine $(R)$ and atmospheric $(A)$ inputs of nitrogen and phosphorus (all in tons ${ }^{*} 10^{3} \mathrm{yr}^{-1}$ ). Data on $\mathrm{N}$ and $\mathrm{P}$ riverine inputs from VOLLENWEIDER et al. (1996); on $\mathrm{N}$ atmospheric input from ERDMAN et al. (1994); on P atmospheric input: from average TIP fluxes in three sub-basins (west to east) of $0.035-0.028-0.021 \mathrm{~g} \mathrm{P} \mathrm{m}^{-2} \mathrm{yr}^{-1}$, respectively.

\begin{tabular}{|c|c|c|c|c|c|}
\hline \multirow[b]{2}{*}{ Sub-basin } & \multirow{2}{*}{$\begin{array}{r}\text { Area } \\
\left(10^{6} \mathrm{~km}^{2}\right)\end{array}$} & \multicolumn{2}{|c|}{ Nitrogen } & \multicolumn{2}{|c|}{ Phosphorus } \\
\hline & & & A & & A \\
\hline WMED & 0.84 & 577 & 459 & 78 & 29 \\
\hline CMED & 0.80 & 212 & 346 & 29 & 22 \\
\hline EMED & 0.70 & 223 & 263 & 30 & 15 \\
\hline Total & 2.34 & 1011 & 1068 & 137 & 66 \\
\hline
\end{tabular}




\subsubsection{Impact of atmospheric phosphorus on primary production.}

Taking the two values from BERGAMETTI et al., (1992) and applying the Redfield ratio (C/P =106/1) gives potential carbon production due to atmospheric dissolved phosphorus input of 0.56 to $1.25 \mathrm{~g} \mathrm{C} \mathrm{m}^{-2}$ $\mathrm{yr}^{-1}$, that is, $11-25 \%$ of the new production of the very oligotrophic zones of the WMED, and one to a few percent for the other more productive zones. The impact of the atmosphere therefore seems to be low for phosphorus; certainly lower than for nitrogen.

The high N/P ratio of atmospheric input $(\sim 70)$ may be responsible for the high N/P ratio $(20-27)$ observed in Mediterranean seawater (HERUT and KROM, 1996).

\subsection{Conclusions and hypotheses}

The relative importance of atmospheric input of nutrients to the Mediterranean increases from the shoreline to the open sea with the decreasing influence of riverine inputs, and from active mixing zones (margin "upwellings", frontal zones) to oligotrophic "stable" zones. On an annual scale, the nitrogen atmospheric input is significant for oligotrophic zones, in which it may account for up to $60 \%$ of new production, whereas atmospheric phosphorus may account for a maximum of $25 \%$.

It is evident that the impact of the atmospheric input of nutrients to the open Mediterranean is difficult to detect, and would in any case be negligible during the period of intense primary production due to mixing with deep rich waters. But during the summer and early fall stratification of the Mediterranean, atmospheric inputs represent a non-negligible source of nutrients (up to $4000 \mu \mathrm{mol} \mathrm{N} \mathrm{m} \mathrm{d}^{-2}$ ), which may trigger small but detectable phytoplankton blooms (Fig. 3.1), as reported by MARTIN et al. (1989).

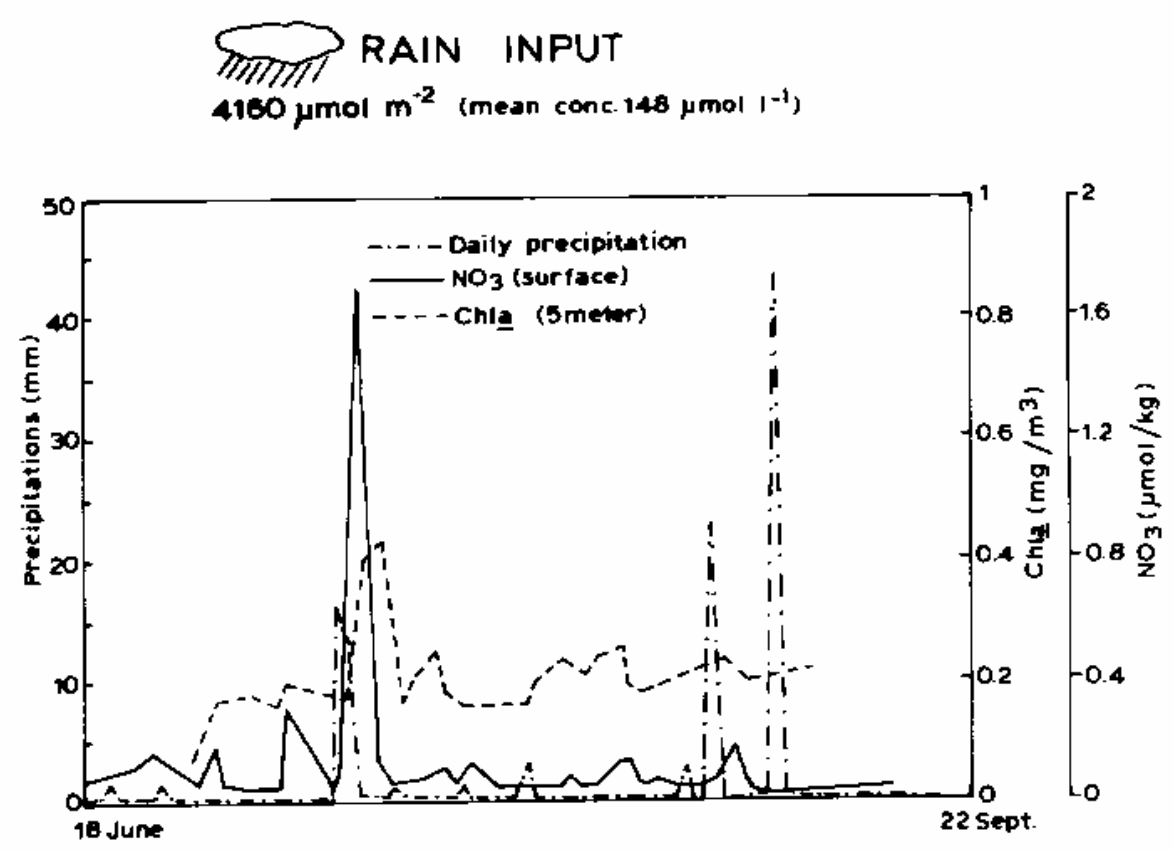

Fig. 3.1 - Wet atmospheric input of nitrogen and its effect on productivity (from MARTIN et al., 1989). 
In this respect, annual atmospheric $\mathrm{N}$ budgets may have little significance, but the episodic character of the atmospheric supply may be significant over short time-spans. An example of this is the wet atmospheric $\mathrm{N}$ deposition pulse which was studied at Villefranche (MIGON et al., 1989). In this case, prior to deposition, oligotrophic conditions persisted and the upper $18 \mathrm{~m}$ of the water column was stratified by a low salinity layer. After the deposition event, the atmospheric $\mathrm{N}$ signature was clearly observed for 21 days. Neglecting the role of phosphorus, this input of $0.23 \mu \mathrm{mol} \mathrm{NI^{-1 }}$ would theoretically be able to induce new production of $16 \mathrm{mg} \mathrm{C} \mathrm{m}^{-2}$ day $^{-1}$.

In the same way, the sporadic input of Saharan dust may be a source of phosphorus, especially when originating from mixed (anthropogenic/Saharan) rains, in which case phosphorus would be partly desorbed and dissolved from the dust. It has been suggested that some summer algal blooms may be explained by such Saharan dust fallout (see section 4.1) (DULAC et al., 1996).

The role of Saharan dust still needs careful assessment, as it may be an important source of phosphorus and iron (see below). The processes and magnitude of phosphorus and iron dissolution from desert dust and their biological impact are important topics to be investigated in the oligotrophic Mediterranean. Two examples of this will be described in the next section.

\section{Potential effects of atmospheric input on surface ocean biogeochemistry: preliminary speculations}

It appears that atmospheric inputs of metals and nutrients to the MED are of similar magnitude to fluvial inputs, although there are several uncertainties which currently prevent us from quantifying the magnitude and chemical effects of these inputs. The next question that should be addressed is whether they are of significance to biogeochemical cycles in the ocean. We will discuss below two examples in which it seems that atmospheric inputs coincide with a biological response.

\subsection{Meteosat and CZCS: a case of P-fertilisation?}

DULAC et al. (1996) presented a study combining monitoring of desert aerosol from Meteosat and of marine phytoplankton from CZCS (Coastal Zone Colour Scanner) in the WMED during summer 1983. Daily Meteosat images in the solar spectrum (visible channel) were used to quantify African dust transport, following the method described in MOULIN et al. (1997a). The CZCS multichannel was used to monitor marine biology activity in the WMED. Estimates of phytoplankton abundances were based on the algorithm of MOREL (1988) using ratios of seawater reflectances at 0.44 and $0.55 \mu \mathrm{m}$ after correction for atmospheric effects (ANDRÉ and MOREL, 1991).

DULAC et al. (1996) observed a particularly strong desert dust transport event at the end of July 1983 (peak on Julian day 209), which yielded a strong dust flux to Mediterranean waters, with a cumulative input up to $1.5 \mathrm{~g} \mathrm{~m}^{-2}$ during the week, as shown in Fig. 4.1. They also analysed about one hundred CZCS images of the Ligurian Sea during the same period, and averaged chlorophyll estimates in a 
region of $100 \times 100 \mathrm{~km}^{2}$ near the DYFAMED station (corresponding to about 10000 CZCS pixels). Any images in which more than half the CZCS pixels were cloudy or in which the geometric standard deviation of the pixels was larger than 1.5 were rejected. Any images in which the satellite signal was contaminated by high desert dust loads were also eliminated, using the near-infrared channel $(0.75$ $\mu \mathrm{m})$ of the CZCS. In all, nearly $90 \%$ of the initial images were rejected; the resulting maps of phytoplankton concentrations are shown in Fig. 4.2. The peak of dust input (equivalent to approximately $9 \mu \mathrm{mol} \mathrm{P} \mathrm{m}^{-2}$ ) was followed, two weeks later, by a significant increase in phytoplankton concentrations, with a peak value of about $0.5 \mathrm{mg} \mathrm{m}^{-3}$ observed on August 16 (day 228). A response time of one week seems reasonable for phytoplankton growth in natural conditions. It is unlikely that the observed increase in phytoplankton concentration was connected with a decrease in summer surface water stratification, since during the whole period the surface wind speed was always lower than $1 \mathrm{~m} \mathrm{sec}^{-1}$.
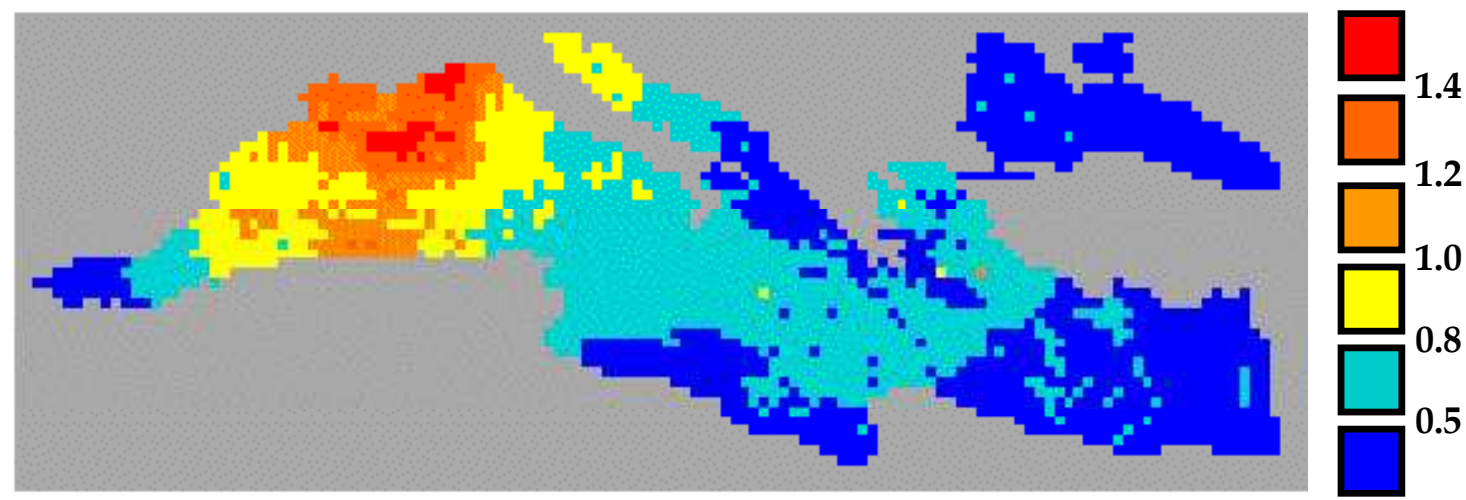

$\mathrm{g} / \mathrm{m}^{2}$

Fig. 4.1 - Meteosat-derived weekly maps of dust input to Mediterranean between July 27 and August 2 1983. Continuous input of African dust occurred during this period, peaking on July 301983. No significant rain was reported during this period. Meteosat daily images allow estimation of dry deposition flux (DULAC et al., 1996) and geographical distribution is also shown. Corresponding dissolved phosphorus input ranges from 5 to $10 \mu \mathrm{g} \mathrm{I}^{-1}$ for NW Mediterranean surface waters.

Assuming $1.5 \mathrm{~g} \mathrm{~m}^{-2}$ of dust, $0.23 \%$ of $\mathrm{P}$ in the dust (GRAHAM and DUCE, 1982) and a solubility of $8 \%$ (LEPPLE, 1971), produces a flux of $9 \mu \mathrm{MP} \mathrm{m}^{-2}$ during this episode. This corresponds to an addition of $9 \mathrm{nM} \mathrm{I}^{-1}$ to a 1-m deep layer. This seems too small to produce a bloom (even assuming surface water $\mathrm{P}$ values as low as $20 \mathrm{nM}$ ). However, we do not really know how much $\mathrm{P}$ dissolved from the dust, so the flux may have been larger than the calculations suggest. Another point is that an input into a highly stratified layer would be more significant. While observations show a biological response after the dust storm, at this stage we do not know what the causal relationship was.

\subsection{Wet deposition of dust: the role of Fe speciation in phytoplankton blooms}

The Cemiliania theory put forward by SAYDAM (1996) suggests that the wet deposition of reduced iron from desert dusts to surface waters of the MED, during the day, has the potential to induce 
phytoplankton blooms. Blooms have been observed several times in the Mediterranean and even in enclosed basins like the Black Sea, and have been linked with prior wet dust deposition events (SAYDAM and YILMAZ, 1998; SAYDAM and POLAT, in press).
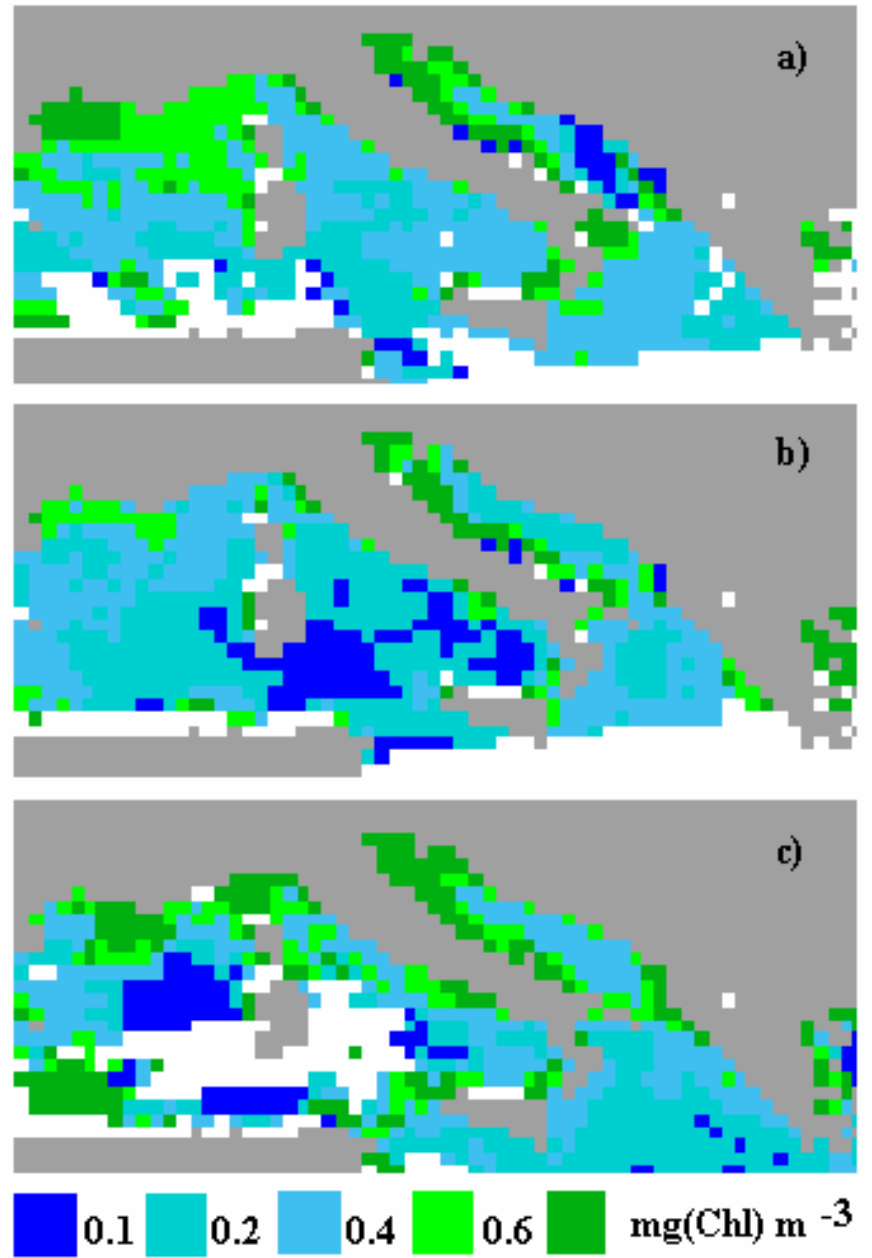

Fig. 4.2 - CZCS-derived weekly maps of phytoplankton concentrations during summer 1983: a) midJune: spring blooms ended, and Ligurian and Adriatic Seas remained relatively productive; $b$ ) early August: during dust deposition event, whole basin exhibited low phytoplankton concentrations, except for coastal zone of Adriatic Sea; c) mid-August: 2 weeks after dust deposition event, unusually high concentrations were observed in Ligurian and Adriatic Seas.

An example occurred during the summer of 1997 over the Central Mediterranean and off the coast of Libya. AVHRR and Meteosat scenes from the period 1-2 June 1997 (F. DULAC, pers. comm.) indicate the transport and possible wet deposition of dust during midday over a position where a subsequent Emiliania huxleii bloom was later observed (Fig 4.4). Synoptic scale meteorological charts also confirm the presence of atmospheric vertical migration and a cold front over the region, supporting the view that wet deposition occurred. 


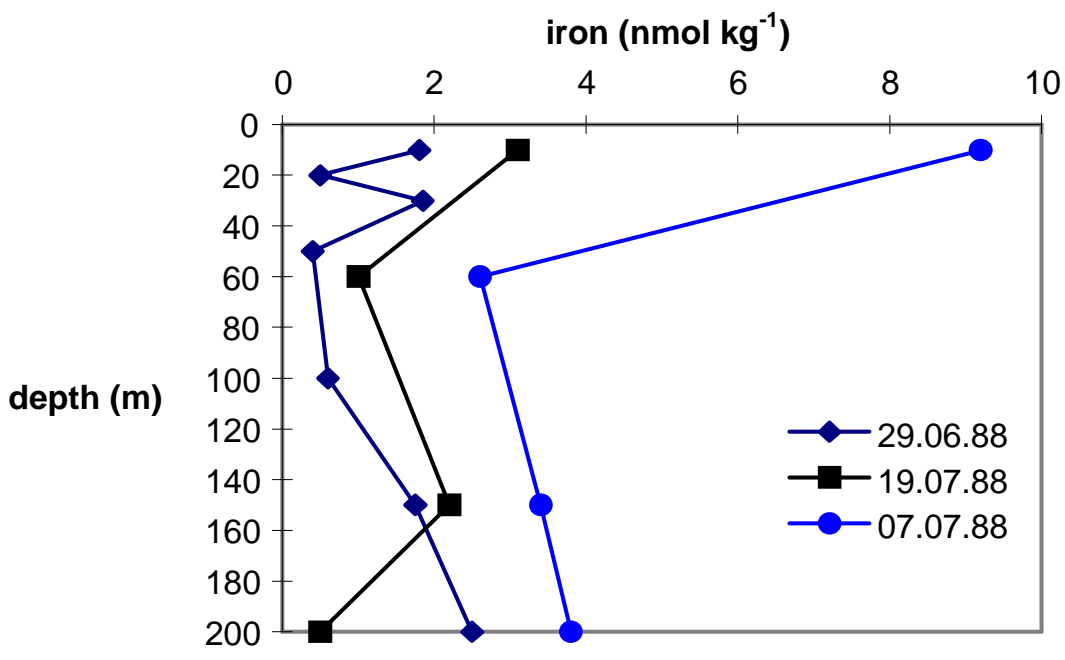

Fig. 4.3 - Vertical profile of particulate iron in surface waters of Ligurian Sea, before and after a major atmospheric input of Saharan dust on July 71988 (from DULAC et al., 1996).

The Cemiliania theory necessitates the presence of "desert-originated dust" for the production of reduced Fe. Laboratory experiments of light-induced dissolution of hematite, goethite and lepidocrosite (SULZBERGER, 1993; SULZBERGER and LAUBSCHER, 1995) with oxalate as reductant ligand have shown that, at $\mathrm{pH}=3$, only photochemical formation of dissolved $\mathrm{Fe}$ (II) occurs with lepidocrosite, but does not result in appreciable amounts of dissolved $\mathrm{Fe}$ (II) when hematite or goethite are used. In confirmation, the revised rainwater sampling strategy of OZSOY (1998) has shown that iron originating from desert sources may be photochemically reduced within cloud droplets to the +2 oxidation state, as suggested by FAUST (1994).

The importance of atmospheric sources in supplying iron to the surface of the open ocean is the subject of some debate. JOHNSON et al. (1997) showed that dissolved iron profiles in the Pacific and Atlantic Oceans have a uniform shape, with a 'nutrient-type' profile. They agree that the major source of iron to the deep sea is eolian transport, but show that integrated (surface to $500 \mathrm{~m}$ ) concentrations are only poorly correlated with eolian iron deposition flux. However, BOYLE (1997) argues that the distribution of iron in deep waters is not well understood, and that the supply of iron to the open ocean is, in fact, predominantly eolian. Evidence of the impact of atmospheric inputs to particulate Fe levels in the MED may be seen in the distributions presented by DULAC et al. (1996). In that work, a dramatic increase in surface water particulate Fe was seen in the Ligurian Sea after a major input of Saharan dust in July 1988 (Fig. 4.3).

Despite the clear impact that atmospheric dust may have on particulate and even dissolved Fe loads in the MED (see section 2.6), it seems unlikely that Fe will limit biological production in this region, since dissolved Fe levels appear to be relatively high ( $>1 \mathrm{nM})$ and macronutrient levels are low. The possibility that it is the deposition of reduced Fe which triggers such events also seems unlikely, since 
a)

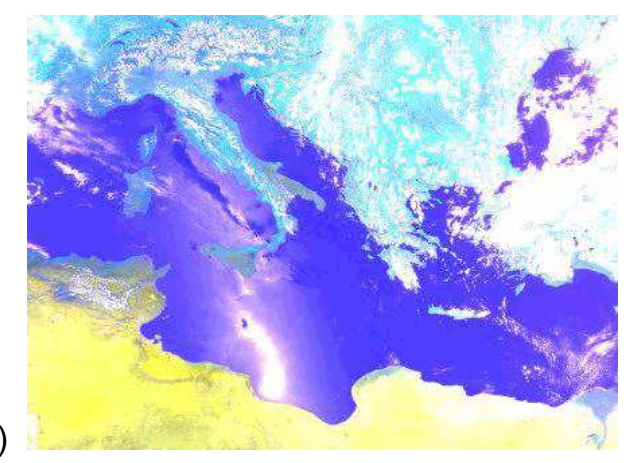

b)

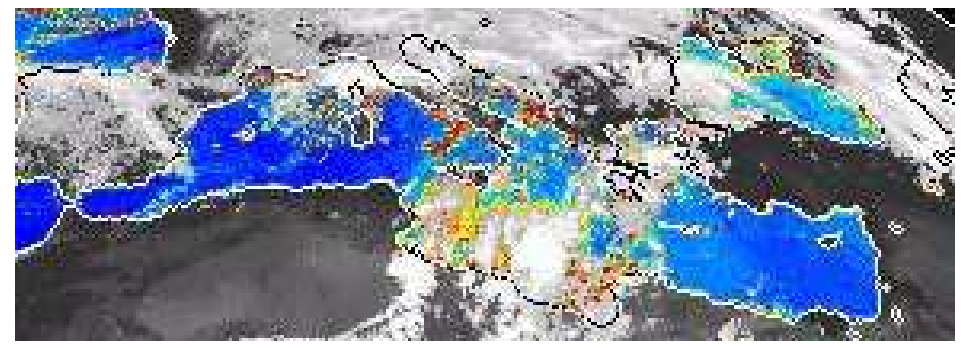

C) Dust Loading $\left[\mathrm{mg} / \mathrm{m}^{2}\right]$
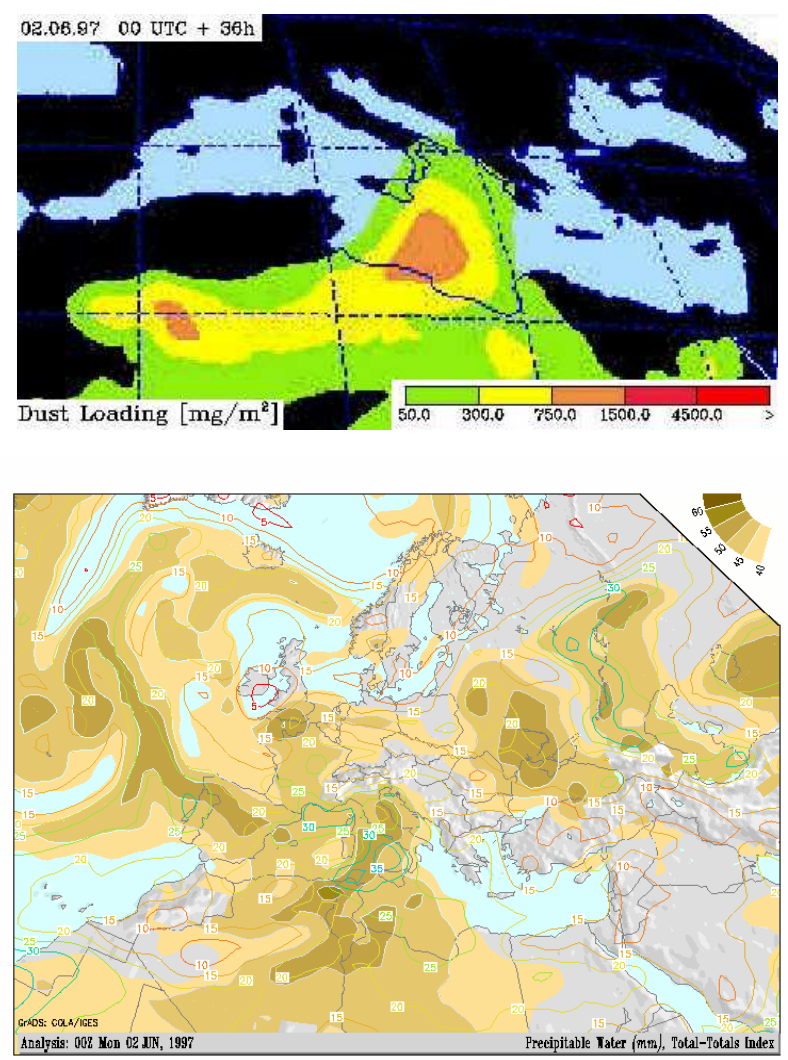

d)

Fig. 4.4 - Four images representing respectively (from top): (a) NOAA-AVHRR composite imagery (June 9 1997), illustrating the high reflection region; (b) ADEOS Hearth Observation Probe UV-absorbing aerosol optical thickness imagery showing the massive dust outbreak over the Sahara and small filaments extending towards the Gulf of Sirte (June 2 1997); (c) dust loading prediction (June 2 1997) from MEDUSE model (http://halo.hi.is/meduse/index.html); and (d) possible wet deposition (June 2 1997) over a vast area offshore Libya, as derived from NOAA-AVHRR composite imagery (VIS and IR). Dust outbreaks in satellite image and deposition model was delivered to sea with rain, and may have triggered Emiliania huxleii bloom observed one week later. 
photochemical reduction of existing surface dissolved iron during daylight hours, as proposed by JOHNSON et al. (1994), would already ensure a sufficient supply.

In order to evaluate this postulated relationship between atmospheric/oceanographic forcing functions and biological responses, it is important to establish whether the links are causal. This needs to be done through direct sampling of ocean and the atmosphere, during a strong Saharan dust event and the following weeks.

\section{Conclusions}

- Average atmospherically deposited annual mass fluxes of dust are estimated at 8-12-35 $\mathrm{g} \mathrm{m}^{-2}$, in the Western Mediterranean (WMED), Central Mediterranean (CMED) and Eastern Mediterranean (EMED) respectively. These fluxes are one-third those of riverine sources.

- Available satellite estimates agree well with the few offshore trap measurements.

- Atmospheric dust deposition is the most important part of the geochemical cycles for some elements (e.g. Pb, Cd, PAH).

- Saharan dust pulses not only perturb the atmospheric conditions above the Mediterranean but, following deposition of this material to the sea surface, they may have a significant effect on the concentration levels of some trace elements in the mixed layer.

- The speciation signatures of some trace metals are different in anthropogenic-rich (European) and crust-rich (Saharan) aerosols; in particular, more of the total concentrations of $\mathrm{Cu}, \mathrm{Pb}$ and $\mathrm{Zn}$ are in exchangeable (potentially mobile) association in the anthropogenic-rich aerosols.

- Atmospherically-transported trace metals are transmitted to marine biogeochemical cycles following the deposition of aerosols at the sea surface by either 'wet' or 'dry' deposition. In both deposition modes, the solubility of the trace metals is constrained by the extent to which they are in exchangeable association in the parent aerosols; but, for the 'wet' deposition, solution $\mathrm{pH}$ and particulate load both impose additional controls.

- The importance of atmospheric input of nutrients to the Mediterranean increases from the shoreline to the open sea with the decreasing influence of riverine inputs, and from active mixing zones (margin "upwellings", frontal zones) to oligotrophic "stable" zones. On an annual scale, the nitrogen atmospheric input is significant for oligotrophic zones, where it may account for up to $60 \%$ of new production, whereas atmospheric phosphorus may only account for a maximum of $25 \%$.

- Biological effects linked with wet and dry atmospheric inputs of nutrients are suggested.

\section{$\underline{5.1 \text { Future work }}$}

Unique information on the geographic source and tropospheric transport of particulate plumes is provided by satellite observations, and the recently launched ocean and multispectral sensors (OCTS, POLDER; SEAWIFS) will allow more extensive and precise monitoring. 
In order to provide insight on the impact of dust events on the chemistry and climatology of an enclosed sea such as the Mediterranean, satellite observations should be:

a) coupled to independent source tracers, including air mass trajectories and chemical tracers such as $\mathrm{Sr}, \mathrm{Nd}$ and $\mathrm{Pb}$ isotopes, and

b) associated with nutrient and trace metal measurements at the onset and during specific events.

Certain specific actions are also recommended (CIESM, 1997):

c) expansion of the present rain/dust collection network in the EMED and SMED regions, to provide more complete regional coverage of dust deposition of the basin;

d) a well-coordinated multidisciplinary research effort should be planned aimed at sampling the atmosphere and the surface MED in real time during and immediately after a Saharan dust event, to take advantage of this natural seeding experiment.

e) a data base should be established, to file existing atmospheric and oceanic information in the Mediterranean; this data base should be available to all workers in the field and could be supported by an international commission such as CIESM (Commission Internationale pour l'Exploration Scientifique de la mer Méditerranée).

\section{Acknowledgements}

This work was partially supported by MTP-MATER Contract MAS3-CT96-0051, STEP Contract CT N080-0080, and World Meteorological Organisation Contract 20.028/A/CNS. This is IGM-CNR scientific contribution no. 1121. We also thank G. Rampazzo and S. Cristini for discussions and trace metal data, G. Cesari for sampling help, G. Quarantotto for chemistry work, G. Zini and E. Masetti for maps and drawings, and $G$. Walton for revision of the english text. We also acknowledge an anonymous reviewer for useful suggestions. Lastly, we thank Frédéric Briand (CIESM director) and Scott Fowler for encouraging us to initiate this work and for supporting it.

\section{References}

ANDERSEN, V. and P. NIVAL (1988) Modèles d'écosystème pélagique des eaux côtières de la mer Ligure. In: Océanographie Pélagique Méditerranéenne, H.J. MINAS and P.NIVAL, editors, Oceanologica Acta, SN 9, pp. 211-217.

ANDRÉ, J.-M. and A. MOREL (1991) Atmospheric corrections and interpretation of marine radiances in CZCS imagery, revisited. Oceanologica Acta, 14, 3-22.

ARIMOTO, R. and R.A. DUCE (1986) Dry deposition models and the air-sea exchange of trace elements. Journal of Geophysical Research, 88, 2787-2792.

AXENFELD, F., J. MUNCH, J.M. PACYNA, J.A. DUISER and C. VELDT (1992) Emissionsdatenbasis fur die Spurenelemente As, $\mathrm{Cd}, \mathrm{Hg}, \mathrm{Pb}, \mathrm{Zn}$ und fur spezielle organische Verbindungen Lindan, HCB, PCB und PAK, Forschungsbericht 10402588 , Umweltforschungsplan des Bundesministers fur Umwelt Naturschutz und Reaktorsicherheit, Dornier, Friedrichshafen. 
BAEYENS, W., F DEHAIRS and H. DEDEURWAERDER (1990) Wet and dry deposition fluxes above the North Sea. Atmospheric Environment, 24A, 1693-1703.

BASHKIN, V.N., L.K. ERDMAN, A.YU. ABRAMYCHEV, M.A. SOFIEV, I.V. PRIPUTINA and A.V. GUSEV (1997) The input of anthropogenic airborne nitrogen to the Mediterranean Sea through its watershed. MAP Technical Reports Series, UNEP, Athens, 118, $95 \mathrm{pp}$.

BERGAMETTI, G. (1987) Apports de matière par voie atmosphérique à la Méditerranée Occidentale. Ph.D. Thesis, Univ. Paris 7 , $296 \mathrm{pp}$.

BERGAMETTI, G., A.L. DUTOT, P. BUAT-MENARD, R. LOSNO and E. REMOUDAKI (1989) Seasonal variability of the elemental composition of atmospheric aerosol particles over the North-western Mediterranean. Tellus, 41B, 353-361.

BERGAMETTI, G., E. REMOUDAKI, R. LOSNO, E. STEINER, B. CHATENET and P.BUAT-MÉNARD (1992) Source, transport and deposition of atmospheric phosphorus over the north-western Mediterranean. Journal of Atmospheric Chemistry, 14, 501-513.

BERLAND, B. R., D. J. BONIN and S. Y. MAESTRINI (1980) Azote ou phosphore? Considérations sur le 'paradoxe nutritionnel» de la mer méditerranée. Oceanologica Acta, 3, 135-142.

BERLAND, B.R., D.J. BONIN, S.Y. MAESTRINI and J.P. POINTIER (1973) Etude de la fertilité des eaux marines au moyen de tests biologiques effectués avec des cultures d'algues. IV. Etude des eaux côtières méditerranéennes. Int. Revue Ges. Hydrobiol., 58, 473-500.

BOYLE, E. (1997) What controls dissolved iron concentrations in the world ocean? A comment. Marine Chemistry, 57, 163- 167.

BOYLE, E.A., S.D. CHAPNICK, X.X. BAI and A. SPIVACK, (1985) Trace metal enrichments in the Mediterranean Sea. Earth and Planetary Sciences Letters, 74, 405-419.

BRULAND, K.W., J.R. DONAT and HUTCHINS, D.A. (1991) Interactive influences of bioactive trace metals on biological production in oceanic waters. Limnology and Oceanography, 36, 8, 1555-1577.

BUAT-MÉNARD, P. (1993) Global change in atmospheric metal cycles. In: Global Atmospheric Chemical Change, C.N. HEWITT and W.T. STURGES, editors, pp. 271-309.

CAQUINEAU, S., A. GAUDICHET, L. GOMES, M-C. MAGONTHIER and B. CHATENET (in press) Saharan dust, Part 1: clay ratio as a relevant tracer to assess the origin of soil-derived aerosols. Geophysical Research and Letters.

CARRATALA, A. J. BELLOT, A. GOMEZ and M. MILLAN (1996) African dust influence on rainwater on the eastern coast of Spain. In: The Impact of Desert Dust Across the Mediterranean, S. GUERZONI and R. CHESTER, editors, Kluwer Academic Publishers, pp. 323-332.

CHESTER, R., M. NIMMO and K.J.T. MURPHY (1989) Atmospheric inputs of trace metals, trace organics and nutrients to the western Mediterranean - The EROS 2000 Programme. Water Pollution Research Reports, 13, 357-367.

CHESTER, R., M. NIMMO and S. KEYSE (1996) The influence of Saharan and eastern desert- dust on the trace metal composition of Mediterranean aerosols and rainwater: an overview. In: The Impact of Desert Dust Across the Mediterranean , S. GUERZONI and R. CHESTER, editors, Kluwer Academic Publishers, pp.253-273.

CHESTER, R., E.J. SHARPLES, G.S. SANDERS and A.C. SAYDAM (1984) Saharan dust incursion over the Tyrrhenian Sea. Atmospheric Environment, 18, n.5, 929-935.

CHESTER, R. M. NIMMO, K.J.T. MURPHY and E. NICOLAS (1990) Atmospheric trace metals transported to the western Mediterranean: data from a station on Cap Ferrat. Water Pollution Research Reports, 20, 597-612.

CHESTER, R., K.J.T. MURPHY, F.J. LIN, A.S. BERRY, G.A. BRADSHAW and P.A. CORCORAN (1993) Factors controlling solubilities of trace metals from non-remote aerosols deposited to the sea surface by the 'dry' deposition mode. Marine Chemistry, 42, 107-126.

CHESTER, R., G.G. BAXTER, A.K.A. BEHAIRY, K. CONNOR, D. CROSS, H. ELDERFIELD and R.C. PADGHAM (1977) Soil-sized eolian dusts from the lower troposphere of the Eastern Mediterranean Sea. Marine Geology, 24, 201-217.

CHOU, L. and R. WOLLAST (1997) Biogeochemical behaviour and mass balance of dissolved aluminium in the western Mediterranean. Deep-Sea Research, 44, 741-768.

CIESM (1997) Role of ocean-atmosphere processes in the biogeochemistry of the Mediterranean Sea, CIESM Workshop Series, 3 , $29 \mathrm{pp}$.

COALE, K.H., K.S. JOHNSON, S.E. FITZWATER, R.M. GORDON, S. TANNER, F.P. CHAVEZ, L. FERIOLI, C. SAKAMOTO, P. ROGERS, F. MILLERO, P. STEINBERG, P. NIGHTINGALE, D. COOPER, W.P. COCHLAN, M.R. LANDRY, J. 
Guerzoni et al.,"The role of atmospheric deposition in the biogeochemistry of the Mediterranean Sea"

CONSTANTINOU, G. ROLLWAGEN, A. TRASVINA and R. KUDELA (1996) A massive phytoplankton bloom induced by an ecosystem-scale iron fertilization experiment in the equatorial Pacific Ocean. Nature, 383, 495-501.

CORNELL, S., A. RENDELL and T. JICKELLS (1995) Atmospheric inputs of dissolved organic nitrogen to the oceans. Nature, 376 , 243-246.

DOLAN, J.R., T.F. THINGSTAD and F. RASSOULZADEGAN (1995) Phosphate transfer between size-fractions in Villefranche Bay (N W Mediterranean Sea ), France in autumn 1992. Ophelia, 41, 71-85.

DOLSKE, D.A. and D.F. GATZ (1985) A field intercomparison of methods for the measurement of particle and gas dry deposition. Journal of Geophysical Research, 90, 2076-2084.

DORTEN, W., F. ELBAZ-POULICHET, L. MART and J.M. MARTIN (1991) Reassessment of the river input of trace metals into the Mediterranean Sea. Ambio, 20, 1, 2-6.

DUCE, R.A. (1986) The impact of atmospheric nitrogen, phosphorus and iron species on marine biological productivity. In: The Role of Air-Sea Exchange in Geochemical Cycling, P. BUAT-MÉNARD, editor, NATO ASI Series, Serie C, 185, pp. 497-529.

DUCE, R.A. (1997) Atmospheric input of pollution to the oceans, Meeting of the World Meteorological Organization Commission for Marine Meteorology, Havana, Cuba, 17 March 1997.

DUCE, R.A., C.K. UNNI, B.J. RAY and R. ARIMOTO (1982) Atmospheric deposition of trace metals to the Tropical North Pacific. Eos, 63, 1987.

DUCE, R.A., P.S. LISS, J.T. MERRILL, E.L. ATLAS, P. BUAT-MENARD, B.B. HICKS, J.M. MILLER, J.M. PROSPERO, R. ARIMOTO, T.M. CHURCH, W. ELLIS, J.N. GALLOWAY, L. HANSEN, T.D. JICKELLS, A.H. KNAP, K.H. REINHARDT, B. SCHNEIDER, A. SOUDINE, J.J TOKOS, S. TSUNOGAI, R. WOLLAST and M. ZHOU (1991) The atmospheric input of trace species to the world ocean. Global Biogeochemical Cycles, 5, 193-259.

DUGDALE, R.C. and J.J. GOERING .(1967) Uptake of new and regenerated forms of of nitrogen in primary productivity. Limnology and Oceanography, 9, 170-184.

DULAC, F., P. BUAT-MÉNARD, M. ARNOLD and U. EZAT (1987) Atmospheric input of trace metals to the Western Mediterranean Sea: 1. Factors controlling the variability of atmospheric concentrations. Journal of Geophysical Research, 92, 8437-8453.

DULAC, F., P. BUAT-MÉNARD, U. EZAT and G. BERGAMETTI (1989) Atmospheric input of trace metals to the Western Mediterranean Sea: uncertainties in modelling dry deposition from cascade impactor data. Tellus, 41B, 362-378.

DULAC, F., C. MOULIN, C.E. LAMBERT, F. GUILLARD, J. POITOU, W. GUELLE, C. QUÉTEL, X. SCHNEIDER and U. EZAT (1996) Quantitative remote sensing of African dust transport to the Mediterranean. In: The Impact of Desert Dust Across the Mediterranean, S. GUERZONI and R. CHESTER, editors, Kluwer Academic Publishers, pp. 25-49.

ELBAZ-POULICHET, F., D.M. GUAN, P. SEYLER, J.M. MARTIN, N. MORLEY, P.J. STATHANM, J.D. BURTON, L. MART and P. KLAHRE (1989) Dissolved trace metals and metaloids in the Rhône River/estuarine system. Water Pollution Research Reports, 13, 357-367.

EMEP (1994) EMEP Workshop on the Accuracy of Measurements, Passau, Germany, November 1993, EMEP/CCC Report 2/94. EPPLEY, R.W. and B.J. PETERSON (1979) Particulate organic matter flux and planktonic new production. Nature, 282, 677-680.

ERDMAN, L.K., M. SOFIEV, S. SUBBOtIN, I. DEDKOVA, O. AFINOGENOVA, T. CHESUKINA, L. PAVLOVSKAYA and A. SOUDINE (1994) Assessment of Airborne Pollution of the Mediterranean Sea by Sulphur and Nitrogen Compounds and heavy metals in 1991, MAP Technical Report Series, UNEP/WMO, Athens, 85, 304 pp.

FAUST, B. (1994) Photochemistry of clouds, fogs, and aerosols. Environmental Science and Technology, 28, 217-222.

FIALA M., G. CAHET, G. JACQUES, J. NEVEUX and M. PANOUSE (1976) Fertilisation de communautés phytoplanctoniques. 1. Cas d'un milieu oligotrophe: Méditerranée nord-occidentale. Journal of Experimental Marine Biology and Ecology, 24, 151-163.

FISHER, D., J. CERASO, T. MATHEW and M. OPPENHEIMER (1988) Polluted coastal waters: the role of acid rain, Environmental Defense Fund, New York, 102 pp.

GANOR, E. and H. FONER (1996) The mineralogical and chemical properties and the behaviour of the aeolian Saharan Dust over Israel. In: The Impact of Desert Dust cross the Mediterranean, S. GUERZONI and R. CHESTER, editors, Kluwer Academic Publishers, pp. 173-182.

GESAMP (1989) The atmospheric input of trace species to the world ocean, WMO Reports and Studies, 38, $111 \mathrm{pp}$.

GRAHAM, W. F. and R. A. DUCE (1982) The atmospheric transport of phosphorus to the western North Atlantic. Atmospheric Environment, 16, 1089-1097. 
Guerzoni et al.,"The role of atmospheric deposition in the biogeochemistry of the Mediterranean Sea"

GUERZONI, S., R. LENAZ and G. QUARANTOTTO (1988) Field measurements at sea: atmospheric trace metals «end-members» in the Mediterranean. Air Pollution Research Report, 14, 96-100.

GUERZONI, S., E. MOLINAROLI and R. CHESTER (1997) Saharan dust inputs to the western Mediterranean Sea: depositional patterns, geochemistry and sedimentological implications. Deep-Sea Reseach, 44, n. 3-4, 631-654.

GUERZONI, S., G. QUARANTOTTO, G. CESARI, E. MOLINAROLI, G. RAMPAZZO and O. LE BOLLOCH (1996) Trace metal composition and grain-size of particulates in aerosols and precipitation collected in N.W. Mediterranean (399N, 9E). In: The Impact of Desert Dust Across the Mediterranean, S. GUERZONI and R. CHESTER, editors, Kluwer Academic Publishers, pp.333-338.

GUERZONI, S., E. MOLINAROLI, P. ROSSINI, G. RAMPAZZO, G. QUARANTOTTO and S. CRISTINI (in press) Role of desert aerosol in metal fluxes in the Mediterranean area. Chemosphere.

GUERZONI, S., W. LANDUZZI, R. LENAZ, G. QUARANTOTTO, G. RAMPAZZO, E. MOLINAROLI, C. TURETTA, F. VISIN, G. CESARI and S. CRISTINI (1993) Fluxes of soluble and insoluble metals and nutrients from the atmosphere to the Central Mediterranean Sea. Water Pollution Research Reports, 30, 253-260.

GUIEU, C. (1991) Apports atmosphériques à la Méditerranée nord-occidentale, Ph.D. Thesis, Univ. Paris 6, 219 pp.

GUIEU, C., A.J. THOMAS, J.M. MARTIN, and J.C. BRUN-COTTAN (1991) Multielemental characterization of the atmospheric input to the Gulf of Lions. Impact upon the upper layer water chemistry. Water Pollution Research Reports, 28, 505-518.

GUIEU, C., R. CHESTER, M. NIMMO, J-M. MARTIN, S. GUERZONI, E. NICOLAS, J. MATEU and S. KEYSE (1997) Atmospheric input of dissolved and particulate metals to the north-western Mediterranean. Deep-Sea Research, 44, 655-674.

HERUT, B., and M. KROM (1996) Atmospheric input of nutrient and dust to the SE Mediterranean. In: The Impact of Desert Dust Across the Mediterranean, S. GUERZONI and R. CHESTER, editors, Kluwer Academic Publishers, pp. 349-358.

HEUSSNER, S., and A. MONACO (1996). The MTP sediment trap experiments: highlights on particle fluxes through the eutrophic and oligotrophic systems of the mediterranean sea. In: Second Workshop of MTP-MAST Programme - Extended abstracts, P. WASSMANN and T. TSELEPIDES, editors, pp. 233-239.

HYDES, D.J., G.J. DE LANGE and H.J.W. DEBAAR (1988) Dissolved aluminium in the Mediterranean. Geochimica et Cosmochimica Acta, 52, 2107-2114.

JOHNSON, K.S., K.H. COALE, V.A. ELROD and N.W. TINDALE, (1994) Iron photochemistry in seawater from the equatorial Pacific. Marine Chemistry, 46, 319-334.

JOHNSON, K.S., R.M. GORDON and K.H. COALE (1997) What controls dissolved iron concentrations in the world ocean?. Marine Chemistry, 57, 137-161.

KEYSE, S. (1995) Trace metal chemistry of Mediterranean rain waters, Ph.D. Thesis, Univ. of Liverpool, UK.

KLEIN, C. (1998) Apports atmosphériques en azote inorganique dissous: dépôt sec par les aérosols et effet des précipitations sur le réseau microbien, Thèse Université $\mathrm{P}$. et $\mathrm{M}$. Curie, Paris.

KROM, M.D., N. KRESS, S. BRENNER and L.I. GORDON (1991) Phosphorus limitation of primary productivity in the eastern Mediterranean Sea. Limnology and Oceanography, 36, 424-432.

KUBILAY, N. S. and A.C. SAYDAM (1995) Trace elements in atmospheric particulates over the Eastern Mediterranean; concentrations, sources, and temporal variability. Atmospheric Environment, 29, 2289-2300.

KUMAR, N., R.F. ANDERSON, R.A. MORTLOCK, P.N. FROELICH, P. KUBIK, B. DITTRICH-HANNEN and SUTER (1995) Increased biological productivity and export production in the glacial Southern Ocean. Nature, 378, 675-680.

LE BOLLOCH, O. and S. GUERZONI (1995) Acid and alkaline deposition in precipitation on the western coast of Sardinia, Central Mediterranean $\left(40^{\circ} \mathrm{N}, 8^{\circ} \mathrm{E}\right)$. Water Air and Soil Pollution, 85 (4), 2155-2160.

LEPPLE, F. K. (1971) Eolian dust over the North Atlantic Ocean. Ph.D. Thesis, Univ. of Delaware.

LIM B., T.D. JICKELLS, J.L. COLIN and R. LOSNO (1994). Solubilities of Al, $\mathrm{Pb}, \mathrm{Cu}$, and $\mathrm{Zn}$ in rain sampled in the marine environment over the North Atlantic Ocean and Mediterranean Sea. Global Biogeochemical Cycles, 8, 349-362.

LOŸE-PILOT, M.D. and J.M. MARTIN (1996) Saharan dust input to the western Mediterranean: an eleven-year record in Corsica. In: The Impact of Desert Dust Across the Mediterranean, S. GUERZONI and R. CHESTER, editors, Kluwer Academic Publishers, pp. 191-199.

LOŸE-PILOT, M.D., J.M. MARTIN and J. MORELLI (1986) Influence of Saharan dust on the rain acidity and atmospheric input to the Mediterranean. Nature, 321, 427-428. 
LOŸE-PILOT, M.D., J.M. MARTIN and J. MORELLI (1990a) Atmospheric wet deposition of inorganic nitrogen to the North Western Mediterranean Basin. Water Pollution Research Reports, 20, 623-634.

LOŸE-PILOT, M.D., J.M. MARTIN and J. MORELLI (1990b) Atmospheric input of inorganic nitrogen to the Western Mediterranean. Biogeochemistry, 9, 117-134.

LOŸE-PILOT, M.D., G. CAUWET, A. SPITZY and J.M. MARTIN (1992) Preliminary results on atmospheric wet deposition of organic carbon and nitrogen in Corsica. Water Pollution Research Report, 28, 519-532.

MALLIN, M.A., H.W. PAERL, J. RUDEK and P.W. BATES (1993) Regulation of estuarine primary production by watershed rainfall and river flow. Marine Ecology Progress Series, 93, 199-203.

MARTIN, J.H. (1990) Glacial-interglacial $\mathrm{CO}_{2}$ change: the iron hypothesis. Paleoceanography, 5, 1-13.

MARTIN, J.M., F. ELBAZ-POULICHET, C. GUIEU, M.D. LOŸE-PILOT and G. HAN (1989) River versus atmospheric input of material to the Mediterranean: an overview. Marine Chemistry, 28,159-182.

MATEU, J., M. COLOM, R. FORTEZA and V. CERDA (1993) Monitoring of major and minor inorganic components of aerosols from the Mallorca station. Water Pollution Research Reports, 30, 261-270.

MAZZUCOTELLI, A., W. LANDUZZI, R. LENAZ, F. OLIVERI, L. TOMADIN and E.R. VANNUCCI (1986) Polveri in sospensione nella bassa atmosfera del Mare Tirreno e del Canale di Sicilia (crociera Ban 80). Memorie della Società Geologica Italiana, 27 , 311-321.

MEASURES, C.I. and J.M. EDMOND (1988) Aluminium as a tracer of the deep outflow from the Mediterranean. Journal of Geophysical Research, 93, 591-595.

MEDINETS, V.I. (1996) Shipboard derived concentrations of sulphur and nitrogen compounds and trace metals in the Mediterranean aerosol. In: The Impact of Desert Dust Across the Mediterranean, S. GUERZONI and R. CHESTER, editors, Kluwer Academic Publishers, pp. 369-373.

MIGON, C. (1993) Riverine and atmospheric inputs of heavy metals to the Ligurian Sea. The Science of the Total Environment, 138, 289-299.

MIGON, C. and J.L. CACCIA (1990) Separation of anthropogenic and natural emissions of particulate heavy metals in the western Mediterranean atmosphere. Atmospheric Environment, 24A, 399-405.

MIGON, C. and E. NICOLAS (1998) Effects of antipollution policy on anthropogenic lead transfers in the Ligurian Sea. Marine Pollution Bulletin, 36, 10, 775-779.

MIGON, C., B. JOURNEL and E. NICOLAS (1997) Measurement of trace metal wet, dry and total atmospheric fluxes over the Ligurian Sea. Atmospheric Environment, 31, 6, 889-896.

MIGON, C., G. COPIN-MONTEGUT, L. ELEGANT and J. MORELLI (1989) Etude de l'apport atmospherique en sels nutritifs au milieu côtier méditerranéen et implications biogéochimiques. Oceanologica Acta, 12, 2, 187-191.

MIGON, C., J. MORELLI, E. NICOLAS and G. COPIN-MONTÉGUT (1991) Evaluation of total atmospheric deposition of Pb, Cd, Cu and $\mathrm{Zn}$ to the Ligurian Sea. The Science of the Total Environment, 105, 135-148.

MIGON, C., L. ALLEMAN, N. LEBLOND and E. NICOLAS (1993) Evolution of atmospheric lead over the NW Med between 1986 and 1992. Atmospheric Environment, 27A, 14, 2161-2167.

MIHALOPOULOS, N., E. STEPHANOU, M. KANAKIDOU, S. PILITSIDIS and P BOUSQUET (1997) Tropospheric aerosol ionic composition in the Eastern Mediterranean region. Tellus, 49B, 314-326.

MILLIMAN, J.D. and J.M. MARTIN (1997) Topical studies in Oceanography. Deep-Sea Research Part II, 44, 521-950.

MILLIMAN, J.D., C.M. RUTKOWSKY and M. MEYBECK (1995) River discharge to the sea. A global river index (GLORI), LOICZ Reports and Studies, 4, pp. 132.

MOLINAROLI, E. (1996) Mineralogical characterisation of Saharan dust with a view to its final destination in Mediterranean sediments. In: The Impact of desert Dust Across the Mediterranean, S. GUERZONI and R. CHESTER, editors, Kluwer Academic Publishers, 153-162.

MOLINAROLI, E. and A. IBBA (1995) Occurrence of palygorskite in aerosol dust (dry and wet) of desert source in SE Sardinia, W Mediterranean. Giornale di Geologia, 57, 67-76.

MOREL, A. (1988) Optical modelling of the upper ocean in relation to its biogenous matter content (Case 1 waters). Journal of Geophysical Research, 93, 10747-10768. 
Guerzoni et al.,"The role of atmospheric deposition in the biogeochemistry of the Mediterranean Sea"

MOREL, A., A. BRICAUD, J.M. ANDRÉ and J. PELAEZ-HUDLET (1990) Spatial/temporal evolution of the Rhone plume as seen by CZCS imagery - Consequences upon the primary production in the Gulf of Lions. Water Pollution Research Reports, 20, 45-62.

MORLEY, N.H., J.D. BURTON, S.P.C. TANKERE and J-M. MARTIN (1997) Distribution and behaviour of some dissolved trace metals in the western Mediterranean Sea. Deep-Sea Research, 44, 675-691.

MOULIN, C., F. GUILLARD, F. DULAC and C. E. LAMBERT (1997a) Long-term daily monitoring of Saharan dust load over ocean using Meteosat ISCCP-B2 data, 1. Methodology and preliminary results for 1983-1994 in the Mediterranean. Journal of Geophysical Research, 102, 16947-16958.

MOULIN,C., E.C. LAMBERT, F. DULAC and U. DAYAN (1997b) Control of atmospheric export of dust from North Africa by the North Atlantic Oscillation. Nature, 387,691-694.

NICOLAS, E., C. MIGON, N. LEBLOND, and B. JOURNEL (1995) Seasonality of dry and wet depositions of trace metals in the Ligurian Sea. Water Pollution Research Reports, 32, 275-285.

NIHLEN, T. and J.O. MATTSSON (1989) Studies on eolian dust in Greece. Geografiska Annaler, 71, $269-274$.

NRIAGU, J.O. and J.M. PACYNA (1988) Quantitative assessment of worldwide contamination of air, water and soils by trace metals. Nature, 333, 134-139.

OWENS, N.J.P., A.P. REES, E.M.S. WOODWARD and R.F.C. MANTOURA (1989) Size-fractionnated primary production and nitrogen assimilation in the Northwest Mediterranean Sea during January 1989. Water Pollution Research Bulletin, 13, $126-135$.

PAERL, H.W., M.L. FOGEL and P.W. BATES (1993) Atmospheric nitrogen deposition in coastal waters: implications for marine primary production and C flux. In: Trends in Microbial Ecology, R. GUERRERO and C. PEDROS-ALIO, editors, Spanish Society for Microbiology, pp. 459-464.

PATTERSON, C.C. and D.M. SETTLE (1987) Review of data on eolian fluxes of industrial and natural lead to the lands and seas in remote region on a global scale. Marine Chemistry, 22, 137-162.

PYE, K. (1992) Aeolian dust transport and deposition over Crete and adjacent parts of the Mediterraean Sea. Earth Surface Processes and Landforms, 17, 271-288.

RAIMBAULT, P. and B. COSTE (1990) Very high values of the nitrate to phosphorus ratio $(>30)$ in the subsurface layers of the western Mediterranean Sea. Rapp. P.-V. Réun. Comm. Int. Mer Mediterr., 32, C18.

REMOUDAKI, E. (1990) Etude des processus contrôlant la variabilité temporelle des fluxes atmosphériques de polluants et de poussières minérales en Méditerranée occidentale, Ph.D. Thesis, Univ. Paris 7, 224 pp.

RODA, F., J. BELLOT, A. AVILA, A. ESCARRE', J. PINOL and J. TERRADAS (1993). Saharan dust and the atmospheric inputs of elements and alkalinity to Mediterranean ecosystems. Water, Air and Soil Pollution, 66, 277-288.

ROSSINI, P. and GUERZONI, S. (1996) Carichi di metalli al mare Adriatico settentrionale attraverso le deposizioni atmosferiche, PRISMA Phase I Workshop, Bologna, Italy, 8-10 October 1996.

RUTTEN, A., G.J. DE LANGE, P. ZIVERI, J. THOMSON, P. VAN SANTVOORT, S. COLLEY and C. CORSELLI (in press) Recent terrestrial and carbonate fluxes in the pelagic eastern Mediterranean; a comparison between sediment trap and bottom sediment. Palaeogeography Palaeoclimatology Palaeoecology.

SANDRONI, V. and C. MIGON (1997) Significance of trace metal medium-range transport in the western Mediterranean. The Science of the Total Environment, 196, 83-89.

SAYDAM, A.C. (1996) Can we predict harmful algae blooms. Harmful Algae News, 15, 5-6.

SAYDAM, A.C. and A. YILMAZ (1998) Dust induced algae growth and the black sea. International Symposium on Fisheries Ecology, Trabzon, Turkey, 2-4 September 1998.

SAYDAM, A.C. and I. POLAT (in press) The impact of saharan dust on the occurrence of algae blooms. In: Proceedings of EUROTRAC Symposium '98, P.M. BORRELL and P. BORRELL, editors, WIT press, Southampton.

SHARP, W.E. and G. NARDI (1987) A study of the heavy metal pollution in the bottom sediments at Porto di Bagnoli (Naples), Italy. Journal of Geochemical Exploration, 29, 31-48.

SLINN, W.G.N. (1983) Air to sea transfer of particles, NATO ASI series, Reidel, Dordrecht, 108, 299-396.

SPITZY, A., W. LUDWIG and M. WOBIG (1990) Survey of amino acid nitrogen in water, sediment and aerosol from the Gulf of Lions. Water Pollution Research Report, 20, 187-193.

SPOKES, L.J. and T.D. JICKELLS (1996) Factors controlling the solubility of aerosol trace metals in the atmosphere and on mixing into seawater. Aquatic Geochemistry, 1(4), 355-374. 
SULZBERGER, B. (1993) The role of heterogeneous photochemical reactions for the formation of dissolved iron species in aquatic systems. Water Pollution Research Reports, 30, 183-186.

SULZBERGER, B. and H. LAUBSCHER (1995) Reactivity of various types of iron(III) (hydr)oxides towards light-induced dissolution. Marine Chemistry, 50, 103-115.

TAYLOR S.R. (1964) Abundance of chemical elements in the continental crust: A new table. Geochimica and Cosmochimica Acta, 28, 1273-1285.

THINGSTAD, T.F. and F. RASSULZADEGAN (1995) Nutrient limitations, microbial foodwebs and "biological pumps": suggested interactions in a P-limited Mediterranean. Marine Ecology Progress Series, 117, 299-306.

TOMADIN, L. (1981) Provenance and dispersal of clay minerals in recent sediments of the Central Mediterranean Sea. In: Sedimentary basins of Mediterranean margins, F.C. WEZEL, editor, pp. 313-324.

TOMADIN, L. and M. BORGHINI (1987) Source and dispersal of clay minerals from present and Late Quaternary sediments of Southern Adriatic Sea. In: 6th Meeting of the European Clay Groups, Spain, pp. 537-538.

TOMADIN, L. and R. LENAZ (1989) Eolian dusts over the Mediterranean and their contribution to the present sedimentation. In: Modern and Past Patterns of Global Atmospheric Transport, M. LEINEN and M. SARNTHEIN, editors, Kluwer Academic Publishers, NATO ASI Series, Series C, 282, 267-282.

TUSSEAU M.H. and J.M. MOUCHEL (1995) Nitrogen inputs to the Gulf of Lions via the Rhone river. Water Pollution Research Reports, 3, 49-59.

UNEP (1984). Pollutants from land-based sources in the Mediterranean, UNEP Regional Seas Reports and Studies No.32.

VENKATARATHNAM, K. and W.B.F. RYAN (1971) Dispersal patterns of clay minerals in the sediments of the Eastern Mediterranean Sea. Marine Geology, 11, 261-282.

VOLLENWEIDER, R.A., A. RINALDI, R. VIVIANI and E. TODINI (1996) Assessment of the state of eutrophication in the Mediterranean Sea. Mediterranean Action Plan Technical Reports Series, No.106.

WINDOM, H., R. SMITH JR, C. RAWLINGSON, M. HUNGSPREUGS, S. DHARMVANIJ and G. WATTAYAKORN (1988) Trace metal transport in a tropical estuary. Marine Chemistry, 24, 293-305.

WOODWARD, E.M.S and N.J.P. OWENS (1989) The influence of the river Rhone upon the nutrient fluxes of the Golfe du Lion. Water Pollution Research Bulletin, 13, 79-86.

ZIVERI, P., G.J. DE LANGE, M. ROSSIGNOL-STRICK, H. SCHRADER and J. THOMSON (1996). Biogechemical cycles in the eastern Mediterranean; Actuo (seasonal/annual) variations. In: 2nd Workshop of Mediterranean Target Project, pp. 217-221.

ZIVERI, P., A. RUTTEN, G. DE LANGE, J. THOMSON and C. CORSELLI (submitted) Coccolith fluxes and their preservation in the central eastern Mediterranean. Palaeogeography, Palaeoclimatology and Palaeoecology. 